Andrzej Klonder

\title{
Świat materii w testamentach szlachty czeskiej i polskiej z XVII wieku
}

Słowa kluczowe: Polska, Czechy, szlachta, testament, wiek XVII

Key words: Poland, Bohemia, nobility, testament, 17th century

I. Wstęp. II. Edycje testamentów. 1. Szlachta polska. 2. Szlachta czeska.

III. Prawo o zawartości testamentów (przepisy, porady, wzorce). IV. Ruchomości w testamentach z Korony Polskiej. 1. Charakter informacji. O czym milczą i mówią testamenty.

2. Rzeczy luksusowe. V. Ruchomości w testamentach z Czech. 1. Charakter informacji.

2. Rzeczy luksusowe. VI. Zakończenie

\section{Wstęp}

Poglądy historiografii polskiej i krajów ościennych (Czech, krajów języka niemieckiego) na rolę testamentu jako źródła poznania dawnej kultury materialnej od dawna są zróżnicowane i stale ewoluują. Na progu wieku XX klasyk polskiej historii prawa, Przemysław Dąbkowski, określił testament za Jakubem Haurem, szlacheckim pisarzem z drugiej połowy XVII w. jako „prawie zwierciadło człowieka żywego"1. Doceniając źródłowe znaczenie testamentu nie wnikał jednak głębiej w szczegóły majątkowych dyspozycji testatorów. Wskazał jedynie, że do ruchomości, którymi swobodnie dysponowali, należały pieniądze, zwierzęta, a nawet niektóre „budowania”2. Z czasem historycy zaczęli poświęcać więcej uwagi rzeczom notowanym w tych dokumentach. Przed laty bez mała trzydziestu Maciej Gołembiowski, historyk i archiwista toruński, charakteryzując testament jako źródło, przypisywał mu wielką wszechstronność. Podkreślał, że - zwłaszcza analizowane w większej liczbie - akty ostatniej woli „wydają się kopalnią wiedzy o zbiorowościach ludzkich w przeszłości i to zarówno o ich duchowości, jak i ży c i u materia 1 n y m" [podkr. - A.K.] . Już w obecnym stuleciu wydawcy jednego z cenniejszych wyborów staropolskich testamentów, we wstępie do tej edycji, w kilkunastu punktach przedstawili dziedziny życia, o których informują testamenty. Znalazła się wśród nich również kultura materialna, rozumiana jednak dość wąsko. Za reprezentatywne dla niej uznali kwestie wyglądu i wyposażenia domostw, narzędzi pracy, ubiorów, inwentarza żywego, ewentualną resztę („itp.”) pozostawiając domyślności czytelników ${ }^{4}$. Ostatnio do entuzjastów testamentów jako źródła dołączyła Elżbieta Elena Wróbel we wstępie do edycji testamentów duchownych diecezji krakowskiej (w części wywodzących się z rodzin szlacheckich).

${ }^{1}$ Dąbkowski P. 1911, s. 81.

2 Dąbkowski P. 1911, s. 80-82.

${ }^{3}$ Gołembiowski M. 1988, s. 159.

${ }^{4}$ Cui contingit nasci. 2005, s. 9. 
Charakteryzując zawartość wydanych aktów stwierdziła: ,jeszcze bogatszy jest [w testamentach — A.K.] świat rzeczy prezentowany niekiedy z całą drobiazgowością skrzętnych gospodarzy. Jest to prawdziwy skarbiec wiadomości o świecie [...], który jest dla potomnych kluczem do zrozumienia czynników warunkujących codzienność tamtych ludzi”' Z kolei, na słabości testamentów jako źródła poznania świata rzeczy, najdobitniej zwróciła uwagę Magdalena Wilczek-Karczewska. Na podstawie materiałów z Wielkopolski stwierdziła m.in. że testament, w odróżnieniu od inwentarza majątku, „nie służył [...] szczegółowej charakterystyce majątku i skrupulatnemu wyliczeniu mobiliów”. Inwentarz „dóbr i rzeczy był natomiast środkiem zabezpieczenia roszczeń w postępowaniu spadkowym"’ . Wreszcie Bożena Popiołek, w monografii poświęconej źródłoznawczej analizie testamentów (zarówno szlacheckich, jak i mieszczańskich), cały podrozdział poświęciła przedstawieniu możliwości, jakie w poznaniu dawanego świata rzeczy daje łączne wykorzystanie inwentarzy i testamentów. Pozyskane ta drogą wiadomości powinny być w miarę możliwości uzupełniane innymi typami źródeł: zapisami dożywocia, intercyzami przedślubnymi, umowami majątkowymi ${ }^{8}$.

Pogląd badaczy czeskich na wartość testamentu jako źródła wydaje się bardziej wyważony. Początkowo zresztą koncentrowali się głównie na mieszczańskich aktach ostatniej woli9. Dopiero później zajęli się testamentami szlacheckimi ${ }^{10}$. Najpełniej poglądy historiografii czeskiej przedstawił obecnie najlepszy, tamtejszy znawca problematyki testamentu szlacheckiego, Pavel Král. Podstawą jego studium obejmującego stulecie 1550-1650 stały się testamenty zachowane w księgach ziemskich wszystkich regionów Czech (ok. 1150 aktów), czyli prawna praktyka. Czeski badacz uszeregował pożytki wynikające $\mathrm{z}$ analizy testamentów w badaniach historycznych. Na pierwszym miejscu postawił ich rolę w tworzeniu prawnej i gospodarczej historii szlachty. Kolejne dziedziny, dla których testamenty są źródłem podstawowym, to badania genealogiczne, demograficzne, studia nad strukturą rodziny. Omawiane dokumenty umożliwiają także rekonstrukcję cyklu życiowego szlachetnie urodzonych, wreszcie poznanie ich mentalności. Dopiero w dalszej kolejności (i to w powiązaniu z inwentarzami mienia) Král przyjmuje, że testamenty to jedno z ważniejszych źródeł wiedzy o kulturze materialnej szlachty i topografii jej majętności. Zawarte w aktach ostatniej woli zapisy na rzecz urzędników, dworzan (przyjaciół i klientów) oraz służby uznaje również za przydatne w badaniach nad strukturą szlacheckiego dworu - familiii ${ }^{11}$. Informacyjna wyższość inwentarzy jako podstawy poznania świata rzeczy otaczających szlachcica sprawia, że za optymalną dla badacza uznaje nieczęstą sytuację, gdy inwentarz stanowi część (załącznik) do testamentu. Niekiedy jednak, jako źródło informacji o majątku ruchomym, testamenty tylko nieznacznie ustępują inwentarzom. Dotyczy to zwłaszcza dokumentów szlachty uboższej. Rzeczy cenne, np. klejnoty, którymi dysponowała, stanowiły istotną część danego majątku. Niektórzy testatorzy rozdzielali szczegółowo wszelkie ruchomości, łącznie ze sprzętami domowymi, bydłem, drobiem i zbożem ${ }^{12}$.

Bliskie poglądom P. Krála wydaje się stanowisko badaczy z krajów języka niemieckiego, głównie historyków prawa i stosunków społecznych. Ostatnio najpełniej przedstawił je Austriak — Leopold Auer. Dostrzega trzy wielkie dziedziny, o których informują testamenty, tj. przede

5 Wróbel E.E. 2016, s. 14. Spór o udziale kapłanów pochodzenia szlacheckiego wśród duchownych diecezji krakowskiej, zob. Wróbel E.E. 2015, s. 580.

${ }^{6}$ Wilczek-Karczewska M. 2011, s. 339.

7 Wilczek-Karczewska M. 2011, s. 338.

8 Popiołek B. 2009, s. 181-197.

9 Por. np.: Pešek J. 1982, s. 63-93; Bůžek V. 2001, s. 13-40; Hrubá M. 2002; Hrubá M. 2015, s. 58-69, tam wcześniejsza literatura.

${ }^{10}$ Por. Život. 1996; Aristokratické. 1999; Hrubá M. 2001, s. 59-80, tam wcześniejsza literatura.

${ }_{11}$ Král P. 2002, s. 56-72, 103, 112; Král P. 2004, s. 477-494.

12 Král P. 2004, s. 64. 
wszystkim kwestie wiary, pobożności, stosunku do śmierci; dalej — problemy rodziny nuklearnej i szerszej familii (krewni, przyjaciele, klienci, służba), kwestie genealogiczne. Na końcu dopiero wspomina stosunki majątkowe, zastrzegając, że dane zawarte w dokumencie mogą nie wystarczyć do rekonstrukcji stanu majątkowego testatora. Można natomiast spodziewać się szczegółów o takich grupach rzeczy jak: książki, obrazy, kosztowności — ozdoby (Schmuckgegenstände), wreszcie meble (Mobiliar) ${ }^{13}$.

Jak wynika z wymienionych publikacji, kwestia przydatności testamentów w badaniach nad kultura materialną szlachty, szczególnie nad otaczającym ją światem rzeczy, nadal zasługuje na refleksję, zaś istotnym impulsem do jej podjęcia są ukazujące się już w bieżącym stuleciu polskie i czeskie edycje źródeł ${ }^{14}$. Poniżej pod tym właśnie kątem omówię informacyjne walory testamentów szlachty z Czech i Korony Polskiej, zwłaszcza z jej prowincji zachodnich (Prusy Królewskie, Wielkopolska), bliższych strukturą gospodarczą i społeczną Czechom oraz Śląskowi niż inne krainy Rzeczypospolitej. Szczególną uwagę zwrócę na Prusy Królewskie, w których rolę wyjątkowo znaczącą w skali całej Rzeczypospolitej odgrywały miasta. Pomocniczo, jako materiał porównawczy, wykorzystam źródła z Małopolski (z województw krakowskiego i sandomierskiego), a także z krajów niemieckich.

\section{Edycje testamentów \\ 1. Szlachta polska}

Edycja testamentów z Prus Królewskich z XVII stulecia obejmuje 111 dokumentów ${ }^{15}$. W odróżnieniu od innych prowincji Korony, w przypadku województw pomorskiego i chełmińskiego, nie pochodzą one z ksiąg sądowych grodzkich; te zachowały się tylko z Dzierzgonia (Kiszporka), dla najmniejszego w Prusach województwa malborskiego. Wydawcy zebrali przede wszystkim szlacheckie akty ostatniej woli rozproszone w archiwach kościelnych (biskupstwa chełmińskiego, konsystorskich, klasztornych); stanowią one połowę zbioru. Pozostałe pochodzą z ksiąg ławniczych miast Prus, z archiwów rodowych szlacheckich, wreszcie z akt sądów grodzkich sąsiednich Kujaw.

Wśród testatorów przeważa szlachta chełmińska (nieco ponad połowa ogółu). Obywatele największego z województw — pomorskiego stanowią niewiele ponad 1/3, reszta to mieszkańcy województwa malborskiego. Zdaniem J. Dygdały, wnikliwego recenzenta wydawnictwa, do elity senatorsko-urzędniczej prowincji należała ok. 1/5 testatorów: Bąkowscy, Cemowie, Działyńscy, Konarscy, Konopaccy, Kosowie, Szczepańscy, Weyherowie, Zawadzcy, „w jakiejś mierze” także Krokowscy, Kruszyńscy, Niemojewscy i Olescy. Najliczniejsza jest grupa szlachty średniej $(2 / 3 \text {, tj. ponad } 30 \text { rodzin })^{16} ; 16 \%$ zbioru stanowią testamenty szlachty drobnej ${ }^{17}$. Według J. Dygdały opublikowane testamenty zawierają ,wyjątkowo dużo informacji na temat sytuacji materialnej poszczególnych testatorów, warunków ich życia i ich interesów finansowych, a także stosunków rodzinnych"18. Czy opinia ta jest w pełni słuszna, pozwolą ocenić dalsze badania.

13 Auer L. 2011, s. 9-10.

14 Przegląd dokonań oraz problemów i zamierzeń związanych z edycją testamentów różnych grup społecznych, w tym także szlachty w dawnej Rzeczypospolitej, zawiera publikacja materiałów „VI Funeraliów Warszawskich” (23-24.X.2014 r.) w: „Kwartalnik Historii Kultury Materialnej”, R. LXIII, 2015, nr 4, s. 569-677. Najnowsze zestawienie edycji w: Klint P. 2018, s. 24-26.

15 Testamenty. 2013; por. Dygdała J. 2014.

${ }^{16}$ M.in.: Bystramowie, Czarlińscy, Dorpowscy, Elżanowscy, Kalksteinowie, Kawieczyńscy, Konojadzcy, Lokowie, Lubodziescy, Mełdzyńscy, Ostromęccy, Pawłowscy, Sampławscy, Sumińscy, Szeliscy, Trebnicowie, Ustarbowscy, Wedelstedtowie, Zegartowscy (Dygdała J. 2014, s. 139).

17 Np.: Choińscy, Cołdańscy, Jajkowscy, Kętrzyńscy, Łękawscy, Nawscy, Niedanowscy, Węsierscy, Prądzyńscy, Zalescy (Dygdała J. 2014, s. 139).

${ }^{18}$ Dygdała J. 2014, s. 140. 
Zbiór wydany przez Wiesława Nowosada i Jacka Kowalkowskiego poprzedziły pojedyncze edycje (najstarsze dziewiętnastowieczne) ogółem 10 aktów ostatniej woli szlachty ${ }^{19}$.

Największą liczbą edytowanych testamentów dysponujemy w przypadku Wielkopolski właściwej. Z tamtejszych województw (kaliskiego i poznańskiego) zachowały się księgi sądów grodzkich, w których najczęściej oblatowywano akty ostatniej woli. Zamierzeniem Pawła Klinta, wydawcy trzech tomów testamentów, było objęcie edycją wszystkich zachowanych aktów, nie tylko zaś tych wybranych. W efekcie tom pierwszy zawiera 105 testamentów wpisanych do ksiąg w latach 1631-1655, czyli jeszcze przed katastrofą Potopu ${ }^{20}$. Testatorzy to głównie szlachta średnia - jedno- i kilkuwioskowa. Magnatem w tym gronie była jedna osoba, do tego w chwili spisywania testamentu (1651 r.) już egzulantka z Litwy, Anna Alojza z Ostrogskich, wdowa po hetmanie i wojewodzie wileńskim, Karolu Chodkiewiczu ${ }^{21}$. Tom kolejny zawiera 201 aktów ostatniej woli z lat 1657-1680. Wśród nich również przeważają testamenty osób średniozamożnych. Tylko trzy należały do rodów senatorskich — Opalińskich, Kretkowskich, Mycielskich ${ }^{22}$. Wreszcie z ostatniego dwudziestolecia XVII w. opublikowano 185 dokumentów ${ }^{23}$. Wśród testatorów także i tu dominują średni posesjonaci, zaś liczebny margines stanowi zarówno grupa urzędniczo-magnacka, jak i pozbawiona posesji gołota (w pierwszym przypadku - 12, zaś w drugim - 11 testamentów). W sumie z siedemdziesięciolecia 1630-1700 dysponujemy korpusem blisko 500 testamentów.

Mniej liczne są wydane ostatnio testamenty szlacheckie z Rusi Czerwonej. Trzej wydawcy opublikowali zbiór ponad 250 siedemnastowiecznych aktów ostatniej woli szlachty ziemi halickiej i sąsiednich ziem czerwono ruskich ${ }^{24}$.

Skala edycji siedemnastowiecznych testamentów szlachty małopolskiej jest mniejsza. Mogą one służyć jedynie jako materiał porównawczy dla Wielkopolski i Prus. Celem wydawców źródeł z Małopolski nie była bowiem publikacja wszystkich aktów z danego okresu, a jedynie ich wyboru, w subiektywnej ocenie oddającego ich różnorodność. Opublikowano testamenty różnych grup szlachty — rodów senatorskich (po części magnackich), szlachty średniej i gołoty. Opracowanie Alicji Falniowskiej-Gradowskiej zawiera 11 testamentów szlachty z województwa krakowskiego z lat 1657-1698. Zostały one wybrane spośród setek zachowanych w księgach grodzkich. W tej grupie testatorów zdecydowanie przeważa szlachta średnia, mamy w niej także jednego senatora - magnata (?) Aleksandra Morsztyna, wojewodę wendeńskiego, bachmistrza wielickiego (1660). Brakuje natomiast najuboższej grupy — gołoty ${ }^{25}$. Zestaw publikowanych testamentów z Krakowskiego uzupełnia edycja z początku XX w. - pięciu aktów z archiwum kolegiaty sądeckiej z lat 1599-1658. Nie ma wśród nich testamentów senatorów, są zaś dokumenty zamożnych familii średnioszlacheckich. Obfitują one w szczegóły dotyczące cennych ruchomości ${ }^{26}$.

Niewielki jest również zasób testamentów z województwa sandomierskiego. Podobnie jak w przypadku Prus Królewskich, wobec zniszczenia ksiąg grodzkich, dokumenty były rozproszone w aktach instytucji kościelnych, miast oraz w księgach grodzkich sąsiedniego wojewódz-

19 Informacje na ich temat, zob. Testamenty. 2013, s. 13-18.

20 Testamenty. 2008.

21 Testamenty. 2008, nr 80 .

22 Testamenty. 2011.

23 Testamenty. 2015.

${ }^{24}$ Testamenty. 2018. Obszernie o zasobach rękopiśmiennych testamentów szlachty prawosławnej i unickiej z terenu Wielkiego Księstwa Litewskiego oraz województw ruskich Korony z okresu od połowy XVI do lat siedemdziesiątych XVIII w. w: Zielecka-Mikołajczyk W. 2012, s. 8, 305-316. O wydawnictwach testamentów z ziem ruskich Korony, por. Zielecka-Mikołajczyk W. 2012, s. 12-13.

25 Testamenty. 1997.

${ }^{26}$ Sygański J. 1910, s. 96-104. 
twa krakowskiego. We wspomnianym powyżej zbiorze ${ }^{27}$ opublikowano 17 szlacheckich testamentów z wieku XVII, 10 z pierwszej połowy stulecia (do roku 1652) oraz 7 z lat 1658-1681. Kilkoro spośród testatorów należało do kręgu senatorsko-magnackiego, pozostali to głównie szlachta średnia. W sumie liczba opublikowanych siedemnastowiecznych testamentów szlachty małopolskiej sięga kilkudziesięciu dokumentów, zawartych w cytowanych zbiorach i w pojedynczych edycjach.

Jeszcze mniej liczne są wydane drukiem testamenty z XVII stulecia szlachty z innych regionów Korony. Z Podlasia kilkanaście opublikował Jan Mamaj ${ }^{28}$. Z Mazowsza dysponujemy pojedynczymi edycjami rozproszonymi w różnych wydawnictwach. $Z$ lat nowszych to choćby publikacja testamentu z roku 1672 Tomasza Gocłowskiego, pana na kilku wsiach, sędziego ziemskiego nurskiego, działacza sejmikowego ${ }^{29}$. Podobnie jest w przypadku Kujaw ${ }^{30}$ i ziemi sieradzkiej ${ }^{31}$.

\section{Szlachta czeska}

Z Czech, oprócz wydawanych jeszcze w XIX stuleciu pojedynczych aktów ostatniej woli najwybitniejszych magnatów ${ }^{32}$, dysponujemy jedną, za to w pełni naukową, obszerną edycją testamentów szlachty z lat 1550-1650. Przygotował ją wspominany już Pavel Král ${ }^{33}$. Wobec ogromu zachowanego materiału (ok. 1150 testamentów z ksiąg ziemskich oraz z archiwów rodzinnych) zmuszony był do wyboru. Jako zasadę przyjął publikację jednego testamentu z każdego roku. Założył także równomierną reprezentację w wydawnictwie dokumentów przedstawicieli obu stanów czeskiej szlachty — prawnie podzielonej na niższy stan rycerski oraz wyższy stan pański, od roku 1627 określany w prawie ziemskim jako hrabiowski-książęcy. Ten ostatni bliski był polskiej magnaterii ${ }^{34}$. P. Král uwzględnił testamenty katolików i protestantów, mężczyzn i kobiet. Próbka dokumentów z lat 1600-1650 liczy 51 pozycji i umożliwia porównanie z siedemnastowiecznymi testamentami z Polski. W tej grupie znalazły się 22 testamenty panów (magnatów?) i 29 rycerzy (szlachty), mężczyzn (32) i kobiet (19). Zakres prezentacji ruchomości nie był dla wydawcy kryterium wyboru tekstu do publikacji. W komentarzu wspomina jedynie o obecności w publikowanym materiale informacji o kulturze materialnej, obok wielu innych ${ }^{35}$.

\section{Prawo o zawartości testamentów (przepisy, porady, wzorce)}

Prawo polskie ograniczało decyzje testatorów w przypadku majątku nieruchomego, w którym zasadą było beztestamentowe dziedziczenie zstępnych. Spadkodawcy mieli natomiast swobodę dysponowania majątkiem ruchomym, takim jak: gotówka, kosztowności (biżuteria, zastawa stołowa z metali szlachetnych), odzież, meble, broń, sprzęty i naczynia domowe, obicia, obrazy, zegary, książki, powozy, inwentarz żywy, płody rolne itp. oraz sumami zapisanymi na dobrach, traktowanymi jako lokaty pieniężne ${ }^{36}$. Dość powszechnym wyjątkiem od tych reguł były testamentowe klauzule „o prawie dożywotniego posiadania części lub całości dóbr ziem-

${ }^{27}$ Cui contingit nasci. 2005, s. 70-142.

28 Testamenty. 2014.

29 Kalinowska B. 2000, s. 125-128.

${ }^{30}$ Por. Śliż N. 2007, s. 91-103.

31 Nowak T.A. 2013, s. 293-302.

${ }^{32} \mathrm{~Np}$. wydany w 1867 r., a spisany w 1634 r. testament kardynała i gubernatora Moraw, Franciszka von Dietrichstein, por. Testament. 1867, s. 411-424.

33 Král P. 2002, s. 115-559 (część źródłowa).

${ }^{34}$ O strukturze i liczebności czeskiej szlachty, nie przekraczającej kilkunastu tysięcy głów panów i rycerzy, por. Bůžek V 1995, s. 8-10.

35 Král P. 2002, s. 106-111.

${ }^{36}$ Pielas J. 2013, s. 19-38, tam wcześniejsza literatura; ostatnio Pielas J. 2016, s. 356-357. 
skich przez pozostającą przy życiu współmałżonkę" ${ }^{37}$. Z tego powodu badacze widzą w testamentach potencjalną skarbnicę danych, zwłaszcza o przedmiotach cennych pod względem materialnym, prestiżowym i emocjonalnym, zarówno dla wyrażających ostatnią wolę, jak i dla beneficjentów testamentu.

Tymczasem o rzeczach, które powinny być uwzględnione w testamencie, kodeksy praw i komentarze do nich informują z reguły tylko ogólnie ${ }^{38}$. Wiadomości tego typu pojawiają się późno, dopiero na przełomie XVIII i XIX w., dotyczą rzeczywistości już zanikającej, zmieniającej się pod wpływem prawa austriackiego i do tego nadal skąpe. Ignacy Lubicz Czerwiński, obywatel galicyjski, prawnik, ludoznawca i moralista, w swoim Przewodniku testatora ${ }^{39}$, opisując stan prawny z czasów po pierwszym rozbiorze Polski, podaje kilka wzorcowych testamentów. Mężczyzna, szlachcic, posiadacz dwóch wsi i 250000 zł kapitału, ojciec czwórki dzieci zastrzega, że nie może szczegółowo rozdysponować „Sprzęty różnego rodzaju srebra, kleynoty, stada bydła itd.”. Dodaje przy tym ,„[...] dopiero po moiey śmierci urząd powinien to będzie otaxować i do massy [spadkowej - A.K.] przyłączyć". Wdowie gwarantuje prawo wybrania „sprzętów moich, które do wygody mieszkania do użytku codziennego potrzebne bydź się znaydą, do wartości 4000 zł. Reszta rzeczy ma być rozdzielona między dzieci, lub zlicytowana a pieniądze podzielone" ${ }^{40}$. W tej części testamentu jest mowa jedynie o kategoriach rzeczy i o ich ogólnej, pieniężnej wartości. Szanse na wskazanie ruchomości szczególnie cennych daje natomiast lista legatów. Żonie szlachcic przekazuje: ,zegar bijący, który zwykł stać w pokoju naszym sypialnym, porcellane wszelkiego gatunku, sztutców srebrnych tuzin, karetę zieloną”, synowi najstarszemu „wszelką broń i konia jednego, z siodłem najlepszym”. Konia ma wybrać sam ze stajni. Jeden z opiekunów żony otrzymuje „tabakierkę złotą, ze szmelcem szafierowym; niech mu z tey rzeczy pamiątką stanie się miłą, bo i mnie za życia mego zawsze się podobała". Jak widać wypadało, aby w testamencie znalazły się uwagi świadczące o sentymencie, zarówno do obdarowanej osoby, jak i do przekazywanego przedmiotu. Inne darowizny nie miały już sentymentalnego tła. Jeden z przyjaciół, Antoni N(nieznany) otrzymał „,pierścień brylantowy o sześciu kamieniach”, inny prawo do ściągnięcia sumy dłużnej 2000 zł ${ }^{41}$.

Z kolei testament żony pozostawiającej męża i dzieci zawiera dyspozycje dotyczące odzieży zmarłej: „Garderobę moią, to iest: suknie i bieliznę oraz to wszystko, co służyło do ubioru ciała mego (wyjąwszy koronki przyszyte, albo nie przyszyte) mąż mój odda sługom moim szlacheckiej i prostej kondycji”. Po wycenie każdy szlachcic będzie mógł wybrać rzeczy o wartości do 200 zł, każdy ,prostak” do 100 zł. Pierwszeństwo wyboru w obu grupach będzie zależeć od „dawności” służby ${ }^{42}$. O samej garderobie testament mówi niewiele, poza pokreśleniem wyjątkowej wartości koronek. W innych wzorcowych testamentach wymieniono wyłącznie legaty pieniężne.

Pozostałe, w tym wcześniejsze polskie zbiory praw i komentarze do nich, nie zawierają modelowych testamentów wskazujących przedmioty, które — zdaniem ich autorów — powinny należeć do typowego zestawu rzeczy przekazywanych spadkobiorcom ${ }^{43}$. Nieco więcej uwagi poświęcano rozróżnieniu ruchomości od nieruchomości, przy czym bardziej precyzyjną definicję tych pierwszych opracowano dopiero w stuleciu XVIII, w Kodeksie Zamoyskiego. Zakres tego pojęcia współcześni badacze odtwarzają przede wszystkim na podstawie samych testamentów, a więc szlacheckiej praktyki prawnej. Informacje o składnikach majątku rucho-

${ }^{37}$ Pielas J. 2015, s. 17.

38 Por. Kutrzeba S. 1921, s. 250-265; Zalaszowski M. 1702, s. 261-284.

${ }^{39}$ Czerwiński I. 1810.

40 Czerwiński I. 1810, s. 162, 166.

${ }^{41}$ Czerwiński I. 1810, s. 166-167.

42 Czerwiński I. 1810, s. 192.

${ }^{43}$ Por. np. Ostrowski T. 1787. 
mego znajdujemy także w zapisach dożywocia dla współmałżonka, w rejestrach posagów, wypraw, a także w aktach podziału majątku (divisio bono rum $)^{44}$.

Szczegółowych regulacji dotyczących zestawu ruchomości uwzględnianych w dyspozycjach testamentalnych brakowało także w Czechach. Według podstawowych aktów prawnych dotyczących dziedziczenia, w testamencie powinny znaleźć się postanowienia dotyczące gotówki, skryptów dłużnych — weksli, klejnotów i najogólniej rzeczy cennych oraz mebli (svrchy a nabitki) ${ }^{45}$. W Ordynacji Krajowej dla Czech (z 1627 r.) i Moraw (z 1628 r. $)^{46}$, w kontekście testamentu jest mowa o pieniądzach, klejnotach i ogólnie ruchomościach (w wersji niem. pares Geld, kleinodien und Farnuß). Choć przepisy dotyczące dziedziczenia zajmują ponad 10 stron, to regulują niemal wyłącznie kwestie formalne związane ze sporządzeniem, uprawomocnieniem, ewentualnie podważeniem testamentu. O dobrach ruchomych, które mogą stać się przedmiotem legatu, wspomina się tylko marginalnie lub przykładowo: puchary-kubki (Becher), futra, wino w fasach, bydło, owce ${ }^{47}$. Z pomocy notarialnych (typu Formelbuch) $z$ epoki znany jest Tutula r Sebastiana Fauknara ${ }^{48}$. Umieszczono w nim tylko jeden wzorcowy testament. ${ }^{49}$ Brak tam jednak danych o strukturze testowanego majątku, nie mówiąc już o uznawanych za nieodzowne dla szlachcica rodzajach ruchomości, bądź tym bardziej o typowych dlań przedmiotach. Dla badacza historii kultury materialnej taki wzorzec testamentu jest $\mathrm{w}$ istocie nieprzydatny ${ }^{50}$.

W praktyce twórcy testamentów (w językach czeskim i od 1627 r. równouprawnionym — niemieckim) korzystali najpewniej ze wsparcia jurystów, pisarzy, wreszcie znających prawo przyjaciół. Innym mogły wystarczać doświadczenie poprzedników oraz wskazówki dość licznych, wydawanych w innych krajach Rzeszy poradników i podręczników. Wcześniej i więcej (niż w przypadkach polskim i czeskim) dowiadujemy się z nich o ruchomościach, jakimi — zdaniem prawników - powinna dysponować szlachta. Bardzo lakoniczny jest jeszcze w tej kwestii Abraham Saur (1545-1593), prawnik, adwokat i prokurator sądu dworskiego Hesji. We wzorcowym testamencie szlachcica zamieścił tylko zwięzły fragment dotyczący zabezpieczenia wdowy. Mogła ona używać dożywotnio całego majątku testatora ${ }^{51}$. Pozostałe dyspozycje dotyczą wyłącznie różnych sum pieniędzy. Być może takie sformułowania we wzorcowych testamentach świadczą też o znacznym upieniężnieniu gospodarki zachodu Rzeszy. Operując wyłącznie kwotami można było uniknąć opisywania wielu bardziej i mniej cennych przedmiotów. Podobnie, w sposób ogólny i powierzchowny, kwestie ruchomości opisano w innym poradniku dla notariuszy i pozostałych twórców testamentów, Institutiones Testamentariae ${ }^{52}$. Jego autorzy działali na południu Rzeszy w pierwszej połowie XVI w. Andreas Peneder był prawnikiem, radcą i sekretarzem elektora bawarskiego. Wolfgang Hunger, doktor obojga praw, wykładał na uczelni w Ingolstadt. Ich dzieło, stale aktualizowane, było wznawiane do początku XVIII w. W wydaniu frankfurcko-lipskim z roku 1721 wspomina się tylko ogólnikowo o majątku ruchomym i nieruchomym, bez wskazówek nawet co do podstawowej struktury tegoż. W specjalnym

44 Pielas J. 2013, s. 21-28; Pielas J. 2009, s. 175; Pielas J. 2004; por. także Sulej K. 2009.

45 Rauscher R. 1922, s. 69-70, 95; Vaněček V. 1964.

46 Landes-Ordnung. 1678, s. 327-338, 408.

${ }^{47}$ Landes-Ordnung. 1678, s. 335, 338.

48 Fauknar ̌̌. 1589.

49 Fauknar S̆. 589, k. 98-100.

${ }^{50}$ Král P. 2004, s. 489. Ostatnio do tematu powstawania testamentów powrócił Tomaš Malý. Stwierdził on powszechność przeświadczenia badaczy o korzystaniu przez spisujących testamenty z materiałów pomocniczych, takich jak np. Formelbuch, z drugiej zaś wskazał tylko jeden przykład takowego z okresu do XVIII w., czyli dzieło Fauknara, Malý T. 2011, s. 111-130.

51 Saur A. 1607, s. 523: aller und jeder anderer meiner liegenden und farhrenden, bewiglichen und unbeweglichen Gütern.

${ }^{52}$ Peneder A., Hunger W. 1721. 
dodatku zamieszczono kilkanaście wzorcowych testamentów ${ }^{53}$. Jeden z nich (datowany na 1721 r.) dotyczy całej spuścizny, zarówno gotówki, jak i pozostałych ruchomości, bez żadnych jednak szczegółów ${ }^{54}$. Do standardu należy dysponowanie przez testatorów różnymi kwotami pieniędzy. Inny, datowany na rok 1716, testament żonatego z hrabianką „,wolnego pana (Freyherr), zawiera np. legaty pobożne od 60 do 600 talarów na świątynie, szpitale, sierocińce, szkoły. Solidną sumą — 20000 talarów zabezpieczona została żona spadkodawcy ${ }^{55}$. Ona też otrzymała majątek ziemski ze wszystkim bydłem, zbożem, gotówką, wierzytelnościami, klejnotami, srebrem oraz innymi mobiliami, nie wyłączając najlichszych. Wyjątkowo zawarto tu wzmiankę o naczyniach do picia (Trinck-Geschirr) ${ }^{56}$.

We wzorcowym testamencie szlachcica zamieszczonym w dziele Adama Volckmanna, prawnika i notariusza działającego w Saksonii w pierwszej połowie XVII w. ${ }^{57}$, oprócz wielu innych, znalazły się też postanowienia dotyczące ruchomości. Przyszłej wdowie testator zapisał 1/3 sreber (pozłacanych i białych); ma też ona swobodnie dysponować wszystkimi sukniami, pierścieniami, łańcuchami, które wniosła w posagu, lub które otrzymała od męża. Pozostałe pieniądze i rzeczy, tj. srebrna zastawa (Silbern Geschirr), suknie (Kleider), książki (Bücher), sprzęty domowe (Haußrath), miały przypaść synowi. Z książek testator wyłączył dzieła prawnicze, które przekazał bratu (być może pełnił on urząd wymagający wiedzy specjalistycznej); pozostałe syn miał sprzedać lub zachowaćs ${ }^{58}$. W tym wzorcu dokumentu oprócz gotówki wymieniono kategorie ruchomości, brak natomiast konkretnych przedmiotów.

Szanse bliższego wniknięcia w świat ruchomości, głównie luksusowych, daje dzieło innego prawnika, notariusza i rajcy z Bazylei (1577-1629), Johanna Rudolfa Sattlera. Jego Thesaurus notariorum $^{59}$, podobnie jak praca Volckmanna, zawiera przykłady aktów ostatniej woli. Sattler operuje nie tylko kategoriami mobiliów, ale również wskazuje określone ruchomości. Nieznana szlachcianka polecała sprzedać swoje pierścienie i klejnoty, zaś uzyskane pieniądze przeznaczyć na potrzeby ubogich i dzieła pobożne. Większość odzieży testatorki miało być równo podzielone między jej dwie siostry oraz ich córki. Jedna z sióstr miała dodatkowo otrzymać noszoną przez testatorkę futrzaną szubę oraz srebrny puchar lub kubek z nakrywką ${ }^{60}$.

W innym miejscu Sattler dokładnie definiuje majątek ruchomy (Fahrende Haab); wyjaśnia jego strukturę oraz podaje przykłady przedmiotów, rzeczy typowych dla poszczególnych kategorii. Tych jest czternaście: klejnoty, suknie (=odzież), broń, zastawa stołowa srebrna, zastawa cynowa, wyroby mosiężne, zastawa drewniana, meble, pościel, wyroby lniane, bydło, winorośl (zarówno grona zebrane, jak i pozostające w winnicy), gotówka, tytuły prawne (renty, czynsze, długi). Wśród klejnotów uwzględnia: pierścienie, łańcuchy, bransolety; wśród odzieży: spodnie, wamsy, płaszcze; wśród zastawy srebrnej: kubki-puchary (Becher), czarki (Schallen) i łyżki. Sattler najczęściej ogranicza się do wskazania trzech przedmiotów. Czasami bywa jednak bardziej wymowny. Wśród zastawy cynowej wylicza: blaty, misy, talerze, konwie, flasze i nalewki ${ }^{61}$.

Dysponując takim wzorcowym materiałem historykowi łatwiej ocenić potencjał informacyjny źródła, a także kompletność zawartych w testamentach wiadomości o ruchomościach.

${ }^{53}$ Peneder A., Hunger W. 1721, s. 153-180.

${ }_{54}$ Peneder A., Hunger W. 1721, s. 163: alle verlassenschaft, sowohl an bahren Gelde als Mobilien.

55 Peneder A., Hunger W. 1721, s. 169-169, 174.

${ }_{56}$ Peneder A., Hunger W. 1721, s. 171: mit allen vorhandenen Vieh, Getreyd, baaren Geld, ausstehenden Schuulde, Kleinodien, Silber und anderen Mobilien, im geringsten nichts davon ausgeschlossen.

57 Volckmann A. 1655.

58 Volckmann A. 1655, s. 252-253.

59 Sattler J.R. 1619. Wcześniejsze wydanie: Francfort am Mayn 1609, wiele wydań późniejszych.

${ }^{60}$ Sattler J.R. 1619, s. 62: silbernen Becher mit dem Deckel.

${ }^{61}$ Sattler J.R. 1619, s. 148. 


\section{Ruchomości w testamentach z Korony Polskiej}

\section{Charakter informacji. O czym milcza i mówia testamenty}

Analiza wspomnianych powyżej polskich wydawnictw źródłowych skłania do powściągnięcia zbytniego, badawczego optymizmu. Część testamentów nie informuje o jakichkolwiek ruchomościach, inne wspominają o nich tylko ogólnie. Nawet te zawierające dyspozycje dotyczące konkretnych mobiliów, często pomijają całe ich kategorie, nawet te wartościowe bądź luksusowe. Przyjrzyjmy się bliżej takim sytuacjom, najpierw na przykładzie P r u s K r óle w s k i c h. Z ponad setki tamtejszych testamentów ok. $60 \%$ nie zawiera żadnych wzmianek — ani ogólnych o kategorii dóbr („,klejnoty”, ,srebra”), ani o przedmiotach, które można zaliczyć do kosztownych (wyroby z metali i kamieni szlachetnych, tkaniny jedwabne, egzotyczne, najdroższe skóry i futra). W ok. 50\% ogółu aktów ostatniej woli uwzględniono dyspozycje pieniężne.

Kwestie gotówki oraz innych cennych rzeczy całkowicie pominął np. Bartłomiej Ostromiecki z Ostromecka, w województwie chełmińskim (1604). Jako miejsce swego spoczynku wskazał tamtejszy kościół, wyznaczył opiekunów siedmiu córek i udzielił instrukcji, co do ich dalszego wychowania. Odnośnie do majątku zadysponował tylko ogólnie: „na wychowanie i ornamenta, także i potrzeby insze wszelakie panienkom [...] mają być z części ich przez PP. opiekuny wydawane”. Wdowie zapisał: „a ta część, na której małżonka moja ma wiano, aby była spokojnie podług jej zapisu zachowana i wolna" ${ }^{62}$. W dokumencie nie podano żadnych kwot oraz szczegółów o ruchomościach. Testator odesłał jedynie do niezachowanego, odrębnego rejestru długów.

Podobnie enigmatyczne sformułowanie zawarła w akcie swej ostatniej woli Anna z Kretkowskich Pieczewska (1614), zapisując mężowi Janowi (który był synem Jana, ławnika ziemskiego malborskiego) przed sądem ławniczym chełmżyńskim: „Wszystkie sumy posagu swego, który mi po rodzicach moich, ze wszystkich dóbr ich, ruchomych i nieruchomych, prawem przyrodzonem przynależały, także insze rzeczy i dobra wszystkie, które mnie [...] należeć mogą". W tekście również nie określono żadnych sum, ani nie wyliczono żadnych rzeczy ${ }^{63}$.

Ogólnikowe są także np. rozporządzenia Elżbiety z Cemów von Polencowej, wywodzącej się z pruskich elit, średniej posesjonatki z województwa malborskiego $(1632)^{64}$. W załączniku do innego testamentu, dotyczącego pieniężnych legatów pobożnych Adama Konopackiego (1649), z uboższej gałęzi senatorskiego rodu, nie wymieniono kwot, a jedynie proporcje udziału darowizna dla poszczególnych instytucji kościelnych (2/3 na kościół, 1/3 na szpital) ${ }^{65}$.

Konkretów zabrakło również w testamencie wojewody malborskiego, Jakuba Wejhera (1657), magnata z prawdziwego zdarzenia, posiadacza blisko 20 wsi własnych, ale także królewszczyzn i starostw: borzechowskiego, bytowskiego, człuchowskiego oraz kiszporskiego. Właśnie królewszczyzny budowały jego magnacki status. Tymczasem w dokumencie znajdujemy jedynie informację o posagu jego żony, Joanny, wojewodzianki brzesko-litewskiej. Miała wnieść małżonkowi, m.in. gotowiznę i klejnoty ${ }^{66}$.

Milczenie magnatów o stanie majątku ruchomego nie było regułą. Inny z Wejherów - Dymitr, zmarły w 1628 r. kasztelan gdański, starosta kościerski i lignowski, w testamencie, obok zapisów pieniężnych zawarł szczegółowy spis należących do niego sreber i klejnotów, przekazywanych „córce mojej miłej”, późniejszej wojewodzinie rawskiej (pimo voto: Andrzej Grudziński) i kasztelanowej łęczyckiej (secundo voto: Paweł Gembicki) ${ }^{67}$.

62 Testamenty. 2013, nr 2, 1604, s. 66-67.

${ }^{63}$ Testamenty. 2013, nr 8, 1614, s. 86-87.

${ }^{64}$ Testamenty. 2013, nr 38, 1632, s. 159-160.

${ }^{65}$ Testamenty. 2013, nr 57, 1649, s. 225-227.

${ }^{66}$ Gdański G. 1996, s. 192-197; Ciara S. 1980, s. 61, 88, 95.

${ }^{67}$ Testamenty. 2013, nr 29, s. 140-145; Ciara S. 1980, s. 37. 
Lakoniczne w opisach ruchomości bywały także testamenty osób z drugiego bieguna zamożności i prestiżu. Wielce niekonkretny jest np. testament Jakuba Pałubickiego (1616), cząstkowego posesjonata spod Kościerzyny, dzielącego między czterech synów zarówno nieruchomości, jak i ruchomości ${ }^{68}$.

Część testatorów, z reguły bogatszych, dysponowała majątkiem ruchomym jedynie w formie pieniężnej. Na przykład Jan Oleski, podkomorzy koronny (w latach 1604-1623 podkomorzy pomorski, a zarazem członek rady Prus Królewskich) postanawiał: „Co się tknie dóbr moich ruchomych [...] leguję i zapisuję ojcom dominikanom klasztoru gdańskiego sumę 30000 zł". Dalej wymieniono inne sumy, aż do drobnych, rzędu 5-10 zł (płace dla służby) ${ }^{69}$. Takie akty (ogółem 22) stanowią ok. 20\% ogółu opublikowanych w analizowanym zbiorze.

Generalnie, w wielu testamentach przedmioty (poza gotówką) wchodzące w skład ruchomej spuścizny są opisywane bardziej lub mniej ogólnie, a zarazem zwięźle.

I tak np. Jabub Bolimiński, prócz Bolimina w województwie chełmińskim pozostawił małżonce „także ruchome rzeczy wszystkie” $(1620)^{70}$. Podobnie Gertruda z Ostromieckich Sumińska stwierdziła: „rzeczy ruchome wszystkie którekolwiek by się znalazły te daje [...] małżonkowi swemu" (1631) ${ }^{71}$. Z kolei zmarła w 1649 r. Anna Elżanowska, dwórka Teresy z Łaszewskich Dzierżkowej, starościny białoborskiej, poleca: „Aby jej wszystkie rzeczki, tak te które przy nas miała, jako i te które w skrzyni u panien zakonnych w Bydgoszczy zostawiła, na kościół byszewski [...] oddane były". O tym, co kobieta miała przy sobie, co zaś kryła skrzynia zdeponowana u klarysek, już się z testamentu nie dowiemy. Zamieszczono w nim jedynie odsyłacz do inwentarza rzeczy przechowywanych w Bydgoszczy ${ }^{72}$. Nieco więcej informacji podaje Stanisław Bielicki, burgrabia grodzki chełmiński (1625), który — oprócz 200 florenów w gotówce — zapisał małżonce „wszystkie dobra [...] ruchome i nieruchome, gieradę, sprzęt, bydło, stado, zasiewek sprzątniony i cokolwiek w domu się najdzie"73.

Podobnie Michał Mełdzyński, zamożny posesjonat z województwa chełmińskiego (6 wsi) (1626), uczynił żonę w przypadku swej śmierci panią dożywotnią na całym majątku, w tym na „ruchomych rzeczach wszystkich, tak w bydłach, w koniach, na wszystkim dobytku moim”74.

Niekiedy testatorzy skrupulatnie wyliczali kategorie rzeczy tworzące majątek ruchomy, lecz bez wskazywania poszczególnych przedmiotów.

Dość dokładnie strukturę majątku mobilnego opisano np. w testamencie Jana i Anny Grudowskich, posesjonatów z okolic Grudziądza (1629). Składały się nań, oprócz pieniędzy, „srebro pozłociste, cyna, miedź, mosiądz, statki kuchenne, szaty, pościele, obrusy, płótna, suknie, futra, konie, klacze, stare i młode, robotne i nierobotne, krowy, woły i insze bydło [...] zboża i sprzęty domowe i wszystkie rzeczy jakimkolwiek imieniem są nazwane". To wszystko małżonkowie oddali sobie nawzajem, zależnie od tego, które z nich umrze pierwsze ${ }^{75}$.

Równie kompletne wydaje się zestawienie dóbr należących do Daniela Orzechowskiego, skromnego właściciela z powiatu grudziądzkiego, ewangelika (1610). W testamencie stwierdził: „Żonie mojej miłej dawam wszystkie rzeczy ruchome, jako te które do sprzętu albo domowego gospodarstwa należą, jako wozy, pługi i insze wszystkie rzeczy do tego należące, także i wóz z przykryciem, po tym cynę, wszystkie lichtarze, moździerze, kotły, kociołki etc. Szatym swoje dzieciom za żywota rozdał, także i tesarzkiego rzemiosła rzeczy jako stoły, ławy, zydle,

\footnotetext{
68 Testamenty. 2013, nr 10, 1616, s. 90-91.

${ }^{69}$ Testamenty. 2013, nr 18, 1626, s. 110-113.

70 Testamenty. 2013, nr 13, 1620, s. 97-98.

71 Testamenty. 2013, nr 34, 1631, s. 151-152.

72 Testamenty. 2013, nr 58, 1649, s. 227, przyp. 2.

73 Testamenty. 2013, nr 22, 1625, s. 121-123.

74 Testamenty. 2013, nr 24, 1626, s. 128-129.

75 Testamenty. 2013, nr 32, 1629, s. 147-149.
} 
szafy, skrzynie, skrzynki [...] zgoła [...] nic sobie nie zostawując. Także też konie, woły, krowy, gęsi, kury etc. dawam, bo też to jej praca"76.

Wśród opublikowanych 105 aktów ostatniej woli z W i e 1 k o p o 1 s k i z lat 1631-1655 tylko trzy, poza ogólnym rozporządzeniem dotyczącym prawa dysponowania całym majątkiem ruchomym, nie zawierają dokładniejszych danych o jego elementach ${ }^{77}$. Najogólniej swoją wolę sformułowała Helena Chrostowska (1649), stwierdzając: „[...] proszę [...] żeby cokolwiek mam z krwaw(e)y mojej wysługi, a ciężki(ej) pracę nic a nic od kochanego małżonka mego nic nie było oddalono". Kobieta doceniła dobroć męża, to że poślubił ją pomimo braku posagu i nie żałował kosztów związanych z jej leczeniem w chorobie. O detalach, najpewniej bardzo skromnego majątku testatorki, nie dowiadujemy się niczego ${ }^{78}$.

Blisko 1/3 ogółu testamentów (32 dokumenty) pośród mobiliów wymienia jedynie pieniądze, wszelkie inne pomijając. Podobnie, wśród testamentów oblatowanych w księgach grodzkich wielkopolskich po szwedzkim Potopie (1660-1680), tylko w ok. 1/3 wspominano o środkach finansowych. Wśród testatorów były zarówno osoby posiadające duże sumy, takie jak Jan Wojnarowski (prawie $20000 \mathrm{zł}$ - dożywocie oraz dzieła pobożne) ${ }^{79}$, jak też uboższe, np. Anna z Wolskich (1664; dysponująca kwotą 200 zł oraz skrzynią z różnymi rzeczami, oddanymi na przechowanie do fary kaliskiej) ${ }^{80}$, czy wreszcie opuszczona przez rodzinę Anna Suchorska (1662), która stwierdziła: „po śmierci mojej ni grosza nie zostaje"81.

Podobnie jak Prusacy, także Wielkopolanie w aktach ostatniej woli o ruchomościach wspominają czasami ogólnie, niekiedy zaś w sposób mniej lub bardziej dokładny, opisując strukturę majątku ruchomego, nie schodząc jednak do poziomu poszczególnych przedmiotów. I tak, np. Maciej Keszycki, raczej ubogi szlachcic (,szlachetny”), oprócz 400 zł zapisał „konie, bydło i rzeczy wszystkie ruchome i nieruchome małżonce swojej [...]" (1645) ${ }^{82}$. Równie hojny i mało precyzyjny był Franciszek Malczewski (1654), który w swoim testamencie stwierdził: „tejże małżonce mojej rzeczy moje wszystkie ruchome i sprzęt domowy, a zgoła wszystkie a wszystkie, jakimkolwiek nazwiskiem mogą być mianowane, jako z nią spólnie nabyte i zapracowane, odkazuję, naznaczam i wiecznymi daruję czasy" ${ }^{\prime 3}$.

Wdowa, Anna z Cieleckich Kuczkowska, postanowiła, aby „rzeczy wszystkie ruchome cokolwiek pozostanie synowi Panu Mikołajowi i z Panią małżonką jego należeć będą" $(1629)^{84}$. Rzeczy tych nie wyszczególniła, natomiast wspomniała o kilku najcenniejszych, przeznaczonych dla wnuczek, córek tegoż Mikołaja. Inna szlachcianka, potrójna wdowa - Barbara z Tłockich, oprócz skrupulatnie odnotowanych kosztowności, przekazała (1636) też „Pościeli i szat dwie skrzynie”, a także „pościel co na niej legam i w czymkolwiek chodzę" ${ }^{85}$. Dorota z Wardęskich darowała synowej ,wszystkie rzeczy ruchome [...] w szatach, w srebrze, w bydle rogatym, w owcach, w koniach i w wszystkich innych rzeczach ruchomych [...]" (1654) ${ }^{86}$. Małgorzata z Chrząstowskich Dokowska, osoba średniozamożna, po rozdysponowaniu między dzieci 8000 zł, pisze o odzieży: „Ostatek tych trochę szat, których niewiele po mnie zostaje, bom się w to nie fundowała”, przekazuje córce Annie, aby „,co potrzebne dała wnuczce”, ,[...] a ostatek

\footnotetext{
76 Testamenty. 2013, nr 7, 1610, s. 84-85.

77 Testamenty. 2008, nr 14, 1634, nr 16, 1635, nr 72, 1649.

78 Testamenty. 2008, nr 72, 1649, s. 144.

79 Testamenty. 2011, nr 125, 1672.

${ }^{80}$ Testamenty. 2011, nr 62, 1664.

${ }^{81}$ Testamenty. 2015, $\mathrm{nr} 48,1662$.

82 Testamenty. 2008, nr 51, 1645, s. 108-109.

${ }^{83}$ Testamenty. 2008, nr 102, 1654, s. 197-199.

${ }^{84}$ Testamenty. 2008, nr 3, 1629, s. 28-30.

${ }^{85}$ Testamenty. 2008, nr 21, 1636, s. 60-61.

${ }^{86}$ Testamenty. 2008, nr 88, 1652, s. 178-180.
} 
ubogim [...] rozdała" $(1656)^{87}$. Marcin Tański, pisarz grodzki wschowski, w dokumencie z roku 1673 „suknie wszystkie” oddał synowcowi Zygmuntowi, wyjątek czyniąc dla kilku, które „ustnie specyfikowanych małżonce mojej naznaczonych” $(1673)^{88}$. Testatorzy nie wyliczali konkretnych ubiorów, ich zdaniem zapewne zbyt mało wartościowych, aby stać się przedmiotem pisemnej dyspozycji.

Wybiórczy charakter edycji testamentów z M a ł o p o ls k i czyni bezprzedmiotowymi analizy statystyczne. Można jedynie stwierdzić, że również wśród nich są takie, w których testator ściśle rozdysponował wyłącznie posiadane sumy pieniężne ${ }^{89}$. W innych, ogólnej formule obejmującej mobilia towarzyszy wskazanie podstawowych składników tworzących ruchome mienie. Tak postąpił np. średniozamożny szlachcic z powiatu opoczyńskiego, Stanisław Jeżowski (2 wsie własne i 1 dzierżawiona). W testamencie (1621) oddał żonie: ,rzeczy wszytkie ruchome, to jest szaty, rystunki moje, konie, dobytki wszelakie, zboża [...] a to nie tylko do używania dożywotniego, ale zupełnie, wiecznie ${ }^{90}$. Wreszcie należący do elity władzy państwa, choć majątku raczej nie, zmarły w roku 1632 inny Małopolanin, podskarbi wielki koronny, krajan z powiatów wiślickiego i pilzneńskiego, Hermolaus Ligęza pozostawił małżonce w dożywocie „ruchome wszytkie rzeczy, jako pieniądze, złoto, srebro, szaty, bydła, konie [...] okrom koni pocztowych i stada". Dalej, nie wchodząc w szczegóły, ograniczył się do poleceń odnośnie do zasobów gotówki ${ }^{11}$.

Praktykę swoistego „lekceważenia” wszystkich, poza pieniędzmi, rzeczy ruchomych, potwierdzają też testamenty z drugiej połowy XVII w. Seweryn Rarowski z Sądecczyzny (1658) po rozdzieleniu sum rzędu od 30 do 2000 zł (posag dla siostrzenicy, dzieła pobożne, płace, koszty pogrzebu),,ruchome rzeczy”, bez drobiazgowego wyliczenia, dał do dyspozycji „księdzu wujowi"92. Strukturę majątku ruchomego poznajemy z testamentu Aleksandra Morsztyna (1660), wojewody wendeńskiego i bachmistrza wielickiego. Ten zapisał żonie dobra ruchome ,jako pieniądze [...] klejnoty, szaty, kobierce, obicia, rynsztunki, konie, karoce, bydło i cokolwiek dóbr moich ruchomych znaleźć się może $[. . .]^{\prime 93}$. W dalszej części tekstu skoncentrował się już tylko o finansach.

Dokładnego wyliczenia przedmiotów o znaczącej, zdaniem testatora wartości, można oczekiwać przede wszystkim w testamentach szlachty średniej. W dokumentach majątkowej elity (familie senatorskie, magnackie) albo brak dokładnych dyrektyw, albo - częściej — poprzestawano na podaniu kwot przewidzianych na zapisy na dobrach, na pokrycie kosztów pogrzebu, fundacje pobożne, dary dla rodziny, klientów i służby, na uregulowanie długów. Odmienną zawartość mają testamenty osób zrujnowanych, bez jakiegokolwiek majątku, w których nie ma jakichkolwiek danych o rzeczach cennych.

Zestaw mobiliów, które posiadali, i o których przeznaczeniu decydowali testatorzy, obejmował: klejnoty, suknie, szaty, futra i pościele; obrusy i płótna, obicia i kobierce, karety i inne pojazdy, broń (,rynsztunki)”, statki kuchenne i inne sprzęty domowe. Wyróżnikiem każdej z tych kategorii był także surowiec, z którego były wykonane - stąd grupy: złota, „sreber”, cyny, miedzi, mosiądzu. Przedmiotem decyzji testatorów były również plony (zebrane i przyszłe, np. zboże) oraz zwierzęta hodowlane (bydło, owce, konie, nawet drób).

Komplet kategorii z tego licznego zestawu z reguły nie występuje w jednym akcie ostatniej woli. Informacje o poszczególnych przedmiotach umieszczano w części dokumentu poświęconej

87 Testamenty. 2011, nr 14, 1656.

${ }^{88}$ Testamenty. 2011, nr 131, 1673, s. 284.

${ }^{89} \mathrm{~Np}$. Jan Gliński, zamożny posesjonat z pow. proszowickiego w woj. krakowskim, Cui contingit nasci. 2005, nr 19, 1620, s. 74-77.

${ }^{90}$ Cui contingit nasci. 2005, $\mathrm{nr} 20,1621$, s. 78-79.

${ }^{1}$ Cui contingit nasci. 2005, $\mathrm{nr} 22,1632$, s. 84.

92 Testamenty. 1997, nr 3, 1658, s. 8.

${ }_{93}$ Testamenty. 1997, nr 4, 1660, s. 10. 
dyspozycjom majątkowym, jednak w różnych kontekstach. Rzadko część (załącznik) testamentu stanowił inwentarz majątku. Taki spis nie ma na celu rejestracji całości spuścizny, lecz jedynie wybranych jej elementów. Mimo to dla badacza historii kultury materialnej jest najcenniejszy ${ }^{94}$. Wzmianki o różnych rzeczach (np. zastawionych) zawarte są też w zestawieniach darowizn, długów należnych i wymagających spłaty, wreszcie legatów pobożnych. Niejednokrotnie sprzedaż cennych przedmiotów miała służyć finansowemu wspieraniu Kościoła. Np. w 1675 r. Maciej Grochowicki, łowczy kaliski, posiadacz kilku wsi w powiecie kcyńskim, zapisał farze w Janowcu na Pałukach gniadego rumaka z rządzikiem i pistoletami. Kwota z ich sprzedaży miała być przeznaczona na potrzeby parafii ${ }^{95}$. Wyroby z metali szlachetnych lub z luksusowych tkanin mogły być także przerabiane lub stać się materiałem, z którego powstawały paramenty kościelne. Np. Stanisław Radowicki, Wielkopolanin „,chodzący dzierżawami” na zachodnich kresach prowincji, przeznaczył w testamencie „,suknię czarną aksamitną na ornat do kościoła w Skrzetuszu” (obecnie Skrzatusz, pow. pilski), równocześnie polecając „wypięcie” ocieplających ją rysi, które przeznaczył dla brata Jakuba ${ }^{96}$. Podobne zarządzenia zawiera także dokument, w którym spisano ostatnią wolę Wojciecha Wężyka, trójwioskowego posesjonaty z powiatu radomszczańskiego, w województwie sieradzkim. Wężyk w części na pobożne cele przeznaczył aksamitny kontusz z ,guzikami szczerozłotymi, jedne z dyjamencikami, drugie z rubinkami”. Te guziki polecił „albo sprzedać, albo z nich kazać zrobić koronę do Najświętszej Panny Wiegomłyńskiej ${ }^{97}$.

\section{Rzeczy luksusowe}

W testamentach, przede wszystkim z uwagi na ich wartość, wzmiankowane są na ogół przedmioty kosztowne, zwyczajowo, a także przez prawo przypisywane stanowi szlacheckiemu. Były wśród nich: klejnoty i biżuteria, paski i guzy, oraz inne wyroby złotnicze, w tym: zastawa stołowa, sztućce, sprzęt oświetleniowy, także służący higienie (misy, nalewki), galanteria warsztatu pisarskiego (kałamarze) oraz paradne uzbrojenie (wykonane po części z metali szlachetnych). Listę takich dóbr uzupełniają w tym czasie najcenniejsze tkaniny (jedwabie), futra (sobole) i skóry (safian, kurdyban), paradne pojazdy oraz wierzchowce. Za takowe bywały też uznawane niektóre dewocjonalia, czasami książki i obrazy.

Wzmianki o tego typu przedmiotach zamieszczono w ok. $40 \%$ testamentów z $\mathrm{P} \mathrm{r} \mathrm{u} \mathrm{s}$ K r ó 1 e w s k i c h, w różnych częściach zaleceń odnośnie do majątku. W ostatniej woli kasztelanica chełmińskiego, Krzysztofa Konopackiego (1610), wśród zapisów dla rodziny, bratankowi Jerzemu Konopackiemu testator przeznaczył na urządzenie gospodarstwa, oprócz obrusów i ręczników (bez szczegółów): „,półmisków 12, mis 2, talerzy tuzin i 2 lichtarze srebrne”. Klasztorowi bernardynów w Nowem, oprócz 200 fl. dał „obrazek srebrny Panny Maryi” oraz parę koni $^{98}$. Tam, gdzie klejnotów było naprawdę wiele, nie wnikano w szczegóły. Kasztelan chełmiński, Stanisław Niemojewski (1620), zalecał: „Klejnoty, choćby za kilka 20000 przedać, bo to niepotrzebne rzeczy, żeby miały próżno leżeć, lepiej z tego pożytek uczynić" ${ }^{99}$. Niemojewskiemu suma 20000 zł najwyraźniej nie imponuje, choć żeby ją uzyskać musiał być właścicielem prawdziwych precjozów. Mimo to nie wyliczył żadnego z nich.

Z kolei Jan i Ewa Niedanowscy z okolicy Nowego Miasta Lubawskiego (ziemia michałowska) informacje o luksusowej odzieży zawarli w dyspozycjach dotyczących dzieł pobożnych (1601). Kościołowi w Kiełpinach pod Działdowem zapisali czapkę letnią aksamitną, drugą futrowaną aksamitną, czepiec aksamitny. Rzeczy te polecili sprzedać, a za uzyskaną sumę

${ }^{94}$ Np. Testamenty. 2013, nr 84; Testamenty. 2008, nr 42, 53; Testamenty. 2011, nr 68, 73.

${ }^{95}$ Górny M. 2002, s. 130-131.

96 Testamenty. 2011, nr 164, 1676, s. 284.

97 Nowak T.A. 2013, s. 300.

98 Testamenty. 2013, nr 6, 1610, s. 81.

99 Testamenty. 2013, nr 15, 1620, s. 106. 
sprawić ornat. Jeszcze jedna aksamitna czapka przypadła ich siostrzenicy ${ }^{100}$. W wykazie długów i ruchomości Małgorzaty z Krupockich Wypczynskiej, także z województwa chełmińskiego (1625), wymieniono darowany niejakiej Pani Bormanowej ,płaszczyk aksamitny felpą podrobiony" oraz bliżej nieokreślony pasek ${ }^{101}$.

Bardziej urozmaicony asortyment ruchomości częściowo zastawionych, rozdysponował Jakub Wałdowski z Krajny (1623), z okolic Więcborka, tuż przy granicy województwa pomorskiego. Z odzieży były to: ferezja podszyta adamaszkiem, czapka sobolowa nowa; z biżuterii — dwa pierścionki małe; z broni — ładownica oprawna srebrem. Do tego jeszcze rusznica, pościel oraz kilka sztuk odzieży wierzchniej. Po sprzedaniu tych rzeczy testator polecał przekazać 1100 zł na potrzeby kościoła w Więcborku i na msze za swoją duszę. Podszewka ferezji miała być przeznaczona na ornat ${ }^{102}$.

Natomiast Wojciech Młodawski, pochodzący z Korony (ziemia sieradzka) „członek domu” rodowitego Prusaka, Fabiana Cemy (starosta sztumski, później kasztelan chełmiński), właściciel wsi Górki w województwie malborskim, wśród darów pobożnych plebanowi sztumskiemu przekazał też „kufel srebrny z wieczkiem”. Podarunek miał wartość nie tylko materialną, ale też sentymentalną, prestiżową. Wieczko zdobiła mianowicie szachownica, herb oraz napis Anna Cemianka. Kufel ten Młodawski otrzymał: ,z łaski sławnej pamięci nieboszczki WP JMP Katarzyny z Leszna Ceminy [córka Andrzeja Leszczyńskiego, wojewody brzesko-kujawskiego —A.K.] mojej miłościwej Pani i dobrodziejki”. „Ku dnowi” Młodawski kazał wyryć swój herb. Tak w jednym przedmiocie utrwalona została historia kariery średniego szlachcica z Korony, który dzięki związkom z rdzenną familią z pruskiej elity dochrapał się w końcu godności deputata województwa malborskiego do trybunału w Piotrkowie (1625). Młodawski rozdał jeszcze kilka innych kufelków zrobionych z tego samego kruszcu. Jeden otrzymał znajomy kaznodzieja luterański, drugi szlachcic JMP Michał Stoliński, ostatni zaś - Jan Reich, doktor malborski, „który częstokroć około zdrowia mego pracował"103.

Testatorzy nadmieniają także o przedmiotach zastawionych. Sprawę taką zasygnalizował wspominany powyżej Daniel Orzechowski (1610 ?). Na wstępie dyspozycji majątkowych stwierdził: „Złota nie mam, srebra trochę i to w zastawie”104. Informacje o srebrach zastawionych w Elblągu uwzględniła w swoim testamencie Barbara z Loków Balińska, chorążyna malborska (1617). Było to kilkadziesiąt wyrobów, w tym: łańcuch (200 zł), konew wielka (40zł), konewki mniejsze dwie, 22 łyżki (w tym 10 mniejszych), kufel turecki „srebrem oprawny”, dwa kubki pozłociste (warte $170 \mathrm{zł).} \mathrm{O} \mathrm{kosztownościach} \mathrm{dowiadujemy} \mathrm{się} \mathrm{też} \mathrm{z} \mathrm{jej} \mathrm{zapisu} \mathrm{dla} \mathrm{dwor-}$ ki Małgorzaty Banisławskiej, zapewne od młodości usługującej chorążynie. Ta, oprócz 1000 zł, sukni, futer i pościeli (nie opisanych dokładniej) obdarowana została innymi, cennymi wyrobami: puzdrem zawierającym łyżki srebrne, „,konewką mniejszą srebrną, z której sama pijam”, a także końmi „wożnikami” (pociągowymi?) i karetą z kobiercami. Osobie bliskiej, choć nie krewnej, dostał się przedmiot osobiście używany przez testatorkę. Konew większa srebrna miała trafić do parafii w Kalwie w powiecie sztumskim, z przeznaczeniem na monstrancję ${ }^{105}$.

Wśród wielu długów (na ogół liczonych w pieniądzu), jakie pozostawił po sobie jednowioskowy posesjonat z województwa chełmińskiego, Jakub Dyra (szlachetny) (1615), odnotowano 5 łyżek srebrnych, którymi rozporządzał jako opiekun dzieci innego szlachcica ${ }^{106}$.

100 Testamenty. 2013, nr 1, 1601, s. 64-65.

101 Testamenty. 2013, nr 19, 1625, s. 114.

102 Testamenty. 2013, nr 16, 1623, s. 107-108.

103 Testamenty. 2013, nr 20, 1625, s. 116-117.

104 Testamenty. 2013, nr 7, 1610?, s. 84.

105 Testamenty. 2013, nr 11, 1617, s. 94.

106 Testamenty. 2013, nr 9, 1615, s. 89. 
Co do asortymentu precjozów z metali szlachetnych i drogich kamieni z Prus, najwięcej testamentów - dwanaście wspomina pierścienie ${ }^{107}$, jedenaście — łańcuchy ${ }^{108}$, dziewięć — łyż$\mathrm{ki}^{109}$, pięć — konwie i konewki ${ }^{110}$; konwie raczej do dostarczania napojów na stół, konewki zaś bezpośrednio do picia. W kilku testamentach odnotowano inne naczynia do konsumpcji napojów: puchary ${ }^{111}$, kufle ${ }^{112}$, kubki ${ }^{113}$, w dwóch — roztruchany ${ }^{114}$ i czarki ${ }^{115}$. W niewielu zamieszczono wzmianki o takich elementach zastawy stołowej jak: talerze ${ }^{116}$, tace ${ }^{117}$, misy i półmiski ${ }^{118}$, wreszcie o widelcach ${ }^{119}$ i solniczkach ${ }^{120}$. Zaskakuje milczenie testatorów na temat srebrnych talerzy i mis, mniej na temat widelców (mimo rewelacji m.in. Kownackiego). Wśród cedowanych sreber (niekiedy pozłacanych) wspomina się też miednice z nalewkami, z reguły używane do mycia rąk przed posiłkiem ${ }^{121}$ oraz lichtarze ${ }^{122}$ i nożyczki do przycinania świec ${ }^{123}$.

Z biżuterii, oprócz najczęściej rejestrowanych pierścieni i łańcuchów, spadkobiercy otrzymują: pasy ${ }^{124}$, zawieszenia ${ }^{125}$, obrączki ${ }^{126}$, manele (bransolety) ${ }^{127}$, sznury pereł ${ }^{128}$. Pojedyncze testamenty wspominają o innych, kosztownych drobiazgach: zaponie ${ }^{129}$, kanaku ${ }^{130}$, zausznicy ${ }^{131}$, portugale (medal lub dukat) ${ }^{132}$, pontale ${ }^{133}$, ,sztuce diamentowej” ${ }^{\prime 34}$, złotym zegarku ${ }^{135}$.

Na szczególną uwagę zasługują klasyfikowane przez testatorów jako część ubioru bądź po prostu jako srebra — guzy (guziki). W niektórych analizowanych dokumentach notki o nich znajdziemy przy opisie poszczególnych strojów. Np. w testamencie posesjonata z województwa chełmińskiego, Jana Antoniego Wołczańskiego (1696), guzy są traktowane jako integralna część odzieży i wymieniane wśród ,sukni”, m.in.: „kontusz kamkowy, jedwabny, guziki krwawnikowe, różyczki złote”, „żupan stary, czerwony, z guzikami złocistemi”" ${ }^{36}$. Niekiedy, po odcięciu od ubioru, były traktowane jako odrębne, wartościowe przedmioty. Wśród rzeczy zapisanych

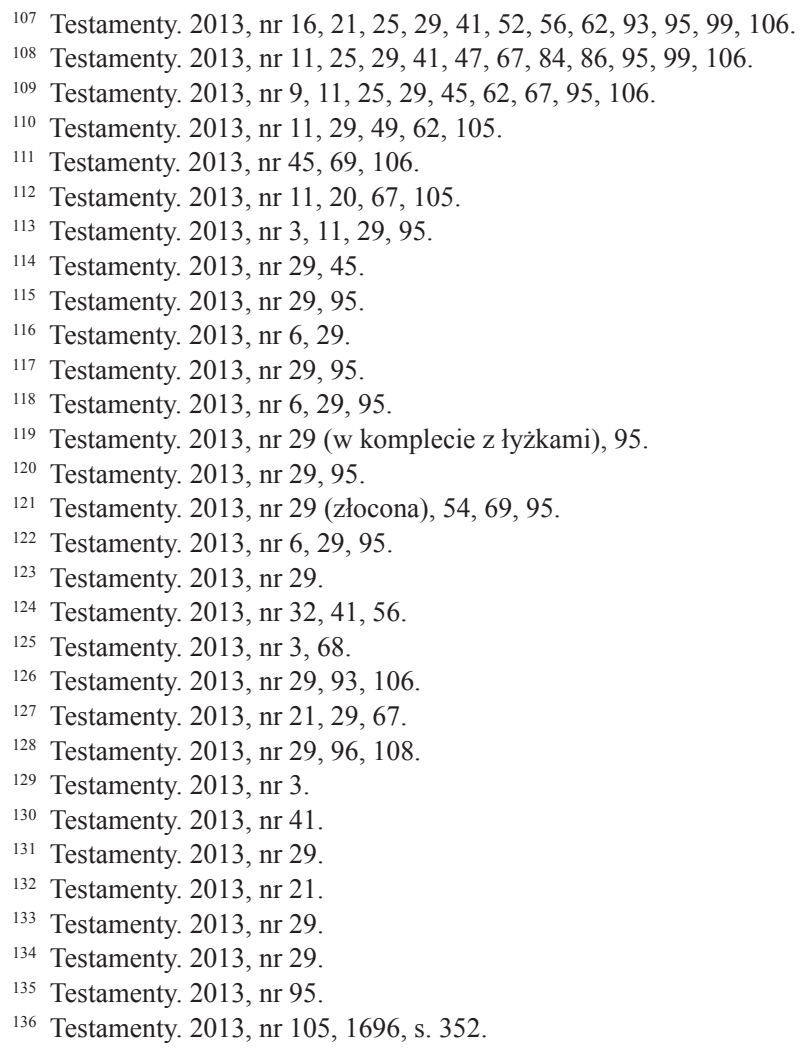


córce przez wspominanego już kasztelana gdańskiego, Dymitra Wejhera (1628), znalazło się kilka rodzajów guzików: „,cztery guzy z smelcem czarnym, złote, 11 guzów z diamentami [...] do delii, 5 guzów wielkich z rubinami do delii, 12 guzików z diamentami i z smalcem do dołomana, 4 guziki z turkusikami, 5 guzików bez diamentów podługowatych i bez kamieni, 15 guzików do dołomanu jednakich z różami, 12 guzików do dołomana mniejszych, 15 jeszcze mniejszych"137. Guziki były tylko niewielką częścią kosztowności darowanych przez kasztelana córce. W zestawieniu z innymi testamentami asortyment przekazanych jej klejnotów oraz sreber wydaje się też najbogatszy. Listę precjozów otwiera „klejnot wielki; gdzie pierścień wielki w nim jest diamentowy", wart 8000 zł, dalej naszyjnik z zawieszeniem diamentowym $(1200 \mathrm{zł})$, zausznice — diamentowe $(3000 \mathrm{zł})$ i rubinowe $(1000 \mathrm{zl}), 6$ pontałów rubinowych (1500 zł), ,perły wszystkie” (1000 zł), „obrączka około szyi, diamentowa” (800 zł), szmaragd zielony (1000 zł), pierścienie ( 2000 zł) łańcuchy (3000 zł), manele diamentowe ( $800 \mathrm{zl).} \mathrm{War-}$ tość biżuterii przekroczyła $23000 \mathrm{z}^{138}$.

Wśród sreber, w sporej części złoconych, królowała zastawa stołowa: łyżki (w tym część z widelcami), dalej „czaszka złota wielka”, różnej wielkości czary, kubki, roztruchany, konwie i konewki, kufel turecki pozłocisty, półmiski z herbami Wejherów, podobnie krużki moskiewskie ozdobione tymiż herbami (zdobyczne?), misy wielkie, tace, w tym „wielka do owoców”, solniczki, w tym jedna „staroświecka z figurami pozłocista”, druga „z łyżeczką i parą nożyków”. Odnotowano nawet takie „drobiazgi” jak „,pokryweczkę od kufla” i „,pół talerza”. Poza zastawą stołową spisano srebrne naczynia kuchenne: kociołek, rynkę, garnuszek. Wejher rozdysponował też przedmioty służące higienie - miednice z nalewkami. Córka otrzymała miednicę półzłocistą z nalewką z jelonkiem i drugą, również pozłacaną, „od Kraicera (?)”. Wśród sreber kasztelana nie zbrakło także lichtarzy (pozłacanych i białych), nożyczek do obcinania knotów, oraz paradnego rynsztunku („rząd pozłocisty”). Był wreszcie posiadaczem wielkiego srebrnego kałamarza, elementu luksusu w pisarskim warsztacie senatora. W tym bogactwie i różnorodności uderza jedynie brak paradnej broni, zarówno białej, jak i palnej. Wartość srebra podano zarówno w wadze kruszcu, jak i w złotych (florenach). Ogółem szacowano ją na blisko 8000 fl. Najcenniejsze mobilia (klejnoty i srebra) odziedziczone po ojcu przez kasztelanównę Annę szacowano łącznie na ponad $30000 \mathrm{zt}^{139}$.

Niemal równie bogaty w informacje jest testament Konstancji z Denhoffów Bąkowskiej, wojewodziny malborskiej $(1685)^{140}$. On także nie zawiera pełnej listy senatorskich kosztowności. Konstancja wspomina ogólnie o srebrze zastawionym, wartości ok. 3000 zł. Zostało spisane w osobnym, niezachowanym rejestrze. W testamencie znalazły się za to decyzje co do losu pozostałych, cennych „drobiazgów”. Należały do nich 2 sztuki „zupełne” diamentowe oraz diamentowy pierścień, oszacowane na 10 000-15 000 zł; z wyrobów złotych:, ,zegarek szczerozłoty firgranowy z łańcuszkiem”, „,kubeczek szczerozłoty, krateczka złota na nim”, łańcuszek i kubek, o wartości ok. 440 zł. Ze sreber w testamencie tym odnotowano: kałamarz, widelce („,widełki w puzdrze czerwonym skórzanym”), „kosz z widelcami”, tace i kubki pozłacane i nie pozłacane, łyżeczki, solniczkę „roboty aupurskiej”, szkatułki, karas (?) i garnuszek. Nie brak też zapisanych Eleonorze Kretkowskiej (krewnej, a zarazem wychowanicy testatorki) drobiazgów do pielęgnacji urody — „mednoczka”, ,galanteryki”, ,porządeczki pokojowe”. „Murzyny”(?) i lichtarze srebrne stojące na półce (listwie) w pokoju, który Konstancja zajmowała w rezydencji krewniaków Bnińskich, miały trafić z tytułu zobowiązań finansowych testatorki do Teresy Boleszowej. Denhoffowa zastrzega przy tym, że z tejże półki nie wolno ruszać srebrnej lampki. Ta jest własnością jej zmarłej służącej, karliczki.

\footnotetext{
137 Testamenty. 2013, nr 29, 1628, s. 143.

138 Testamenty. 2013, s. 142.

139 Testamenty. 2013, s. 142-143.
} 
Krótką, choć szczegółową listę sreber, włączono do testamentu obywatela ziemi chełmińskiej, Jana Antoniego Wołczańskiego (1696). Informacje dotyczą trzech przedmiotów oraz ich dalszego przeznaczenia. Brak tu danych o wartości oraz wadze kruszcu, za to poznajemy pochodzenie, technikę zdobienia i pojemność niektórych naczyń. I tak, „,konewka srebrna auszpurską robotą, biała o stofie dobrym [co najmniej 1,4 1 - A.K.], z wiekiem”, została przeznaczona na lampę do najświętszego sakramentu w kościele „misjonarzów chełmińskich”; „kufel pstrozłocisty z pokrywką" o tej samej pojemności miał być sprzedany. Za uzyskaną kwotę miał być fundowany kielich mszalny. „Kubek mały w capę biały i czareczkę małą, wybijaną, białą” testator darował stryjecznemu, zobowiązując go do dobrych uczynków w swojej intencji. Wołczański wspomniał jeszcze, niestety już tylko ogólnie, o 18 przedmiotach dostarczonych złotnikowi w Grudziądzu. Miał je przerobić na miseczkę z ampułkami do mszy świętych ${ }^{141}$.

O szczegółach wyglądu biżuterii informują też testamenty szlachty uboższej. Np. Zofia z Łukockich Cołdańska, właścicielka części wioski w powiecie świeckim (1626), wspomina o łańcuchu złotym „w młyńskie ogniwa sfalcowanym” wartości 250 zł. Była jego współwłaścicielką wraz z siostrą. Jej wyłączną własnością był natomiast ,pasek srzebrny pozłocisty w młyńskie kółka"142.

Informacje o drogiej odzieży zawiera od ok. 1/5 (z pierwszej połowy XVII w. do 1655 r.) do 1/4 testamentów (z drugiej połowy XVII w.) z Prus Królewskich. Szlachta, także z innych prowincji, $z$ reguły nie podawała wartości poszczególnych elementów ubioru ${ }^{143}$. W tej sytuacji podstawowym wskaźnikiem uznania szat za najcenniejsze jest materiał, z którego były wykonane. Tkaniny takie jak jedwab, adamaszek (kamka), aksamit, atłas, felpa[?], kitajka, saja (półjedwabna), tabin, przeważnie były importowane z zachodu i południa Europy, albo z Turcji i Persji. Drugim, kosztownym elementem stroju były futra (po części także importowane) - sobole, rysie, popielice. Luksusowego sznytu dodawały też odzieży pasamony, koronki, a także wspomniane powyżej, często drogie guzy — guziki, niekiedy należące do precjozów jubilerskich. Czasami owe wyszukane materiały stanowiły jedynie dodatek, ozdobę odzieży wykonanej z tańszych tkanin. Wśród ubiorów wierzchnich, notowanych w pierwszej połowie XVII stulecia, po kilka testamentów wspomina o tradycyjnych (noszonych już w XVI w.) ferezjach ${ }^{144}$ i deliach ${ }^{145}$. Z ubiorów spodnich tylko w jednym dokumencie wzmiankowano o tradycyjnym dołomanie ${ }^{146}$, w innym (z roku 1645) o nowomodnym żupanie ${ }^{147}$. Najwięcej, bo sześcioro testa-

140 Testamenty. 2013, nr 95, 1685, s. 324-328.

141 Testamenty. 2013, nr 105, 1696, s. 351-352.

142 Testamenty. 2013, nr 25, 1626, s. 132.

143 Takie informacje odnalazłem tylko w kilku testamentach z Wielkopolski. W 1657 r. Marianna z Rożnowskich zapisała spadkobiercom resztę majątku bardzo uszczuplonego przez wojnę - $1000 \mathrm{zł}$ oraz bydło, owce i pościel. Przy okazji przypomniała, że jedna z pasierbic już wcześniej (przed wojną?) otrzymała dwie suknie — jedną wartą 90, drugą zaś - 80 zł, do tego 3 sznurki pereł i pasek srebrny złocony, warte zł 30 (Testamenty. 2011, nr 23, 1657, s. 72). Prawdziwym rarytasem jest testament Jakuba z Kaliny Kalińskiego, podczaszego sanockiego, skoligaconego z senatorskimi rodzinami z Małopolski (Dąbscy, Skotniccy, Zamoyscy.) Dokument oblatował w grodzie gnieźnieńskim syn podczaszego, ksiądz (?) Franciszek Kaliński. Obok innych dóbr testator przeznaczył dla dzieci następujące suknie: dwa kontusze aksamitne podbite futrem sobolowym, warte odpowiednio 3000 i $5000 \mathrm{zl}$, oraz kolejne dwa aksamitne kontusze podbite futrem rysia — pierwszy grzbietami (za $2000 \mathrm{zl}$ ), drugi — ,ślamami” (1000 zł) (Testamenty. 2011, 1661, nr 43, s. 117). W roku 1678 w testamencie Barbary z Łukomskich Grabowieckiej (wdowa po sekretarzu królewskim i administratorze ceł) znajdujemy dyspozycje dotyczące trzech zastawionych kontuszy. Aksamitny, zielony, rysi, kupiony za florenów 500, zastawiono za 330 zł, drugi — ,pupkami pięknymi z przodu podszyty, w tyle trochę podszyty” był do wykupienia za 60 zł. Wreszcie trzeci „sajetowy, rysimi nóżkami podszyty" obciążony był sumą zastawną złotych 30 (Testamenty. 2011, nr 173, s. 367).

144 Testamenty. 2013, nr 14, 16, 45.

145 Testamenty. 2013, nr 14, 16, 45, 52.

146 Testamenty. 2013, nr 14.

${ }^{147}$ Dwa żupany należące do drobnego posesjonata z ziemi chełmińskiej — jeden karmazynowy (tkanina nieznana?), drugi falendyszowy zielony, trudno zaliczyć do garderoby luksusowej, Testamenty. 2013, nr 52, s. 208. 
torów zdecydowało o dalszych losach swoich czapek lub czepca ${ }^{148}$. Wśród cennych tkanin najczęściej wymieniano aksamit ${ }^{149} \mathrm{i}$ adamaszek ${ }^{150}$, rzadziej określany ogólnie jedwab $^{151}$, atłas ${ }^{152}$, tabin $^{153}$ lub półjedwabną saję ${ }^{154}$. Z futer na ogół rejestrowano sobole ${ }^{155}$ użyte na podszycie lub obszycie czapek, czasem też kontusza lub żupana. W pojedynczych testamentach odnotowywano te najkosztowniejsze i wyszukane - rysie ${ }^{156}$ i popielice ${ }^{157}$.Typowy dla pierwszej połowy XVII w. jest akt ostatniej woli Wojciecha Pepłowskiego (1638), z pochodzenia Mazowszanina z powiatu płockiego, jednak wżenionego w dobra Ostrowite w województwie chełmińskim. Część testamentu tego rotmistrza wojsk koronnych ${ }^{158}$ ma charakter spisu mienia ${ }^{159}$, zaś część dyspozycji majątkowej ${ }^{160}$. W inwentarzu wykazano zarówno nieruchomości, jak i sumy pieniężne, zapisy dłużne, srebra zastawione, wreszcie inne ruchomości zgrupowane w działy: „Szaty”, „Srebro”, „Strzelba”, „Bydło rogate”, „Konie”, „Owce”. Wśród szat spisano: „Ferezje trzy półszkarłatne czerwone, jedna pupkami a dwie atłasem podszyte. Ferezja półgranatnia futrem lisiem grzbietowem z kołnierzem podszyta. Delijki dwie, atłasowa jedna zieloną kitajką podszyta, a druga wiśniowa, karmazynowa popielicami podszyta, kurt trzy, aksamitna czerwona, adamaszkowa wiśniowa, trzecia starsza adamaszkowa lazurowa, wszystkie z guzikami złocistemi, czapka aksamitna sobolem podszyta" ${ }^{161}$. Co do ich losów testator zadecydował następująco. Paweł Płonczyński, siostrzeniec rotmistrza, miał otrzymać ferezję czerwoną, kurtę adamaszkową wiśniową, czapkę aksamitną, a także część oręża. Obdarowani zostali także panowie bracia z rodziny Beklewskich - Wojciech, Jan i Bartosz. Zapisano im ferezje bez cennych podszewek. Te miały być przeznaczone na uszycie ornatów do kościoła parafialnego w Ostrowitem, gdzie rotmistrz chciał być pochowany. Bratu stryjecznemu Szymonowi zapisał delijkę zieloną atłasową ${ }^{162}$. Pozostałe ubrania, w tym wcześniej nie wspominane (mniej cenne?) — ferezja lisia z kołnierzem, czapka „wydrzana” i buty, miały zostać sprzedane.

Testamenty szlachty pruskiej z drugiej połowy XVII w. zawierają odmienny obraz asortymentu i kroju odzieży; wtedy panują już kontusze i żupany ${ }^{163}$. Tylko w jednym testamencie — Jana Świętosławskiego, posesjonata z powiatu gdańskiego (1657), nadmieniono o staromodnej, ale cennej ferezji ${ }^{164}$. W odróżnieniu od pierwszej połowy stulecia brak wzmianek o deliach i dołomanach. Tak jak wcześniej, dość często wspominano o nakryciach głowy — czapkach $^{165}$, rzadziej o kołpakach ${ }^{166}$. Jedna, ogólna informacja dotyczyła „sukni niemieckich”167. Z kolei w testamencie Agnieszki z Boninów Sulickich Parskowskiej (1671) z parafii wejherowskiej,

148 Testamenty. 2013, nr 1, 16, 45, 49, 52.

149 Testamenty. 2013, nr 1, 14, 15, 32, 45, 52.

150 Testamenty. 2013, nr 14, 16, 45, 52, 62.

151 Testamenty. 2013, nr 12, 62.

152 Testamenty. 2013, nr 15, 45.

153 Testamenty. 2013, nr 52.

154 Testamenty. 2013, nr 49.

155 Testamenty. 2013, nr 16, 45, 49, 52.

156 Testamenty. 2013, nr 49.

157 Testamenty. 2013, nr 55.

158 Testamenty. 2013, nr 45, s. 178-184.

159 „Rzeczy tedy mnie do szafunku od Pana Boga powierzone to są”, Testamenty. 2013, s. 178-180.

160 Testamenty. 2013, s. 180-184.

161 Testamenty. 2013, s. 179.

162 Testamenty. 2013, s. 183.

163 Testamenty. 2013, nr 68, 69, 70, 74, 86, 94, 105, 110, 111.

164 ,[...] rysia, szkarłatna noskami podszyta”, Testamenty. 2013, nr 70, 1657, s. 263.

165 Testamenty. 2013, nr 70, 74, 84, 86, 94, 105.

166 Testamenty. 2013, nr 105, 111.

167 Testamenty. 2013, nr 70. 
w wyodrębnionym inwentarzu rzeczy odnotowano m.in. aksamitną spódnicę oraz „szustokur do tej spódnicy"168. Zapiska to dość tajemnicza, skoro szustokor to według literatury ${ }^{169}$ dopasowany wierzchni kaftan męski, przyjęty we francuskiej modzie cywilnej od ok. 1670 r. Tak więc nowinka z Francji dotarłaby w okolice Wejherowa bardzo szybko i to w wersji damskiej.

W omawianym okresie nie uległ zmianie zestaw cennych materii — tkanin i futer. Żupany i kontusze były uszyte, albo przynajmniej ozdobione, lub zaopatrzone w podszewki z aksamitu ${ }^{170}$, atłasu $^{171}$, adamaszku ${ }^{172}$, kitajki ${ }^{173}$. Wśród futer najczęściej wspomniano o sobolach ${ }^{174}$, w pojedynczych testamentach o popielicach ${ }^{175}$ i rysiach ${ }^{176}$. Stanowiły one podszycie lub ozdobę różnych sztuk odzieży. Czapkę „błękitną kitajczaną”, należącą do wspominanej powyżej parafianki wejherowskiej, Agnieszki Parskowskiej, zdobiła „złota koronka z ogonkami sobolemi, druga czapkę - czarną, tego samego koloru koronka i ogonki sobole ${ }^{177}$.

Analiza testamentów z W i e 1 k o p o $1 \mathrm{~s} \mathrm{k} \mathrm{i} \mathrm{z} \mathrm{lat} \mathrm{1631-1655} \mathrm{daje} \mathrm{w} \mathrm{przypadku} \mathrm{sreber}$ i klejnotów obraz bardzo zbliżony do tego z Prus Królewskich. Najwięcej dyspozycji majątkowych (jedenaście) dotyczyło srebrnych guzów — guzików ${ }^{178}$. Nieco rzadziej decydowano o przeznaczeniu łańcuchów i pierścieni (każde w 8 aktach ostatniej woli) ${ }^{179}$. W siedmiu testamentach wspomniano o manelach ${ }^{180}$, w pięciu o perłach ${ }^{181}$.

Wśród sreber dominowały łyżki, wspominane w co szóstym testamencie ${ }^{182}$. Towarzyszyły im kufle (w 5 dokumentach) ${ }^{183}$, konwie ${ }^{184}$ oraz czary ${ }^{185}$ (każdy z dwóch ostatnich w 4 testamentach). Niekiedy własnością wielkopolskich testatorów były niespotykane w testamentach pruskich flasze ${ }^{186}$, beczułki ${ }^{187}$, dzbany ${ }^{188}$ i nożenki ${ }^{189}$. Brak natomiast wiadomości o widelcach (nie dziwi to jeszcze w pierwszej połowie XVII w.). Nieco obszerniejsza wydaje się w Wielkopolsce lista sreber kuchennych, a wśród nich — durszlaczek, kociołek, tygiel ${ }^{190}$. Dwa pierwsze wraz z dwiema łyżkami zabrał na pospolite ruszenie Wojciech Modrzewski z województwa poznańskiego $(1651)^{191}$.

Z kilku aktach ostatniej woli, zawierających spisy zastawy o charakterze inwentarzowym wynika, że wspominane w pojedynczych testamentach z Wielkopolski srebrne naczynia — pu-

168 Testamenty. 2013, nr 84, s. 294.

169 Turnau I. 1999, s. 182.

170 Testamenty. 2013, nr 69, 70, 74, 86.

171 Testamenty. 2013, $\mathrm{nr} 70,74,76$.

172 Testamenty. 2013, nr 105, 111.

173 Testamenty. 2013, nr 84, 94, 95, 105.

174 Testamenty. 2013, nr 74, 84, 86, 94, 105.

175 Testamenty. 2013, nr 70 s.263, ,kontusz atlasowy zielony popielczami podszyty i bobremi opuszany”.

176 Testamenty. 2013, nr 110, s. 369, „kontusz sukienny rysiami podszyty”.

177 Testamenty. 2013, nr 84, s. 294.

178 Testamenty. 2008, nr 5, 8, 31, 36, 40, 42, 53, 57, 66, 85, 87.

179 Testamenty. 2008, łańcuchy — nr 40, 42, 53, 57, 63, 81, 85, 87; pierścienie — nr 9, 29, 39, 40, 49, 53, 57,63 .

180 Testamenty. 2008, nr 40, 42, 53, 61, 81, 87.

181 Testamenty. 2008, $\mathrm{nr} 40,53,57,85,104$.

182 Testamenty. 2008, nr 3, 4, 9, 11, 18, 19, 25, 40, 42, 53, 57, 61, 63, 66, 77, 89, 104.

183 Testamenty. 2008, nr 5, 53, 66, 77, 87.

184 Testamenty. 2008, nr 49, 53, 61, 87.

185 Testamenty. 2008, nr 40, 42, 49, 66.

186 Testamenty. 2008, nr 53.

187 Testamenty. 2008, nr 53.

188 Testamenty. 2008, nr 53.

189 Testamenty. 2008, nr 40, 71.

190 Testamenty. 2008, nr 53, 77.

191 Testamenty. 2008, nr 77, 1651, s. 149. 
chary ${ }^{192}$, kubki ${ }^{193}$, lub całkowicie w nich nieobecne misy, półmiski i talerze, były zastępowane, przez cenioną i również dzieloną testamentalnie cynę ${ }^{194}$. Np. „,szlachetna” (a więc raczej z drobnej szlachty) Zofia, wdowa po Wojciechu Wolskim, młynarzu z okolic Wałcza, rozdzieliła między dwóch synów, oprócz bardzo skromnych sreber (pas i 4 łyżki), cynę: 12 mis z półmiskami i „dwie konewce” (1633). Gdyby Zofia zmarła, owe wyroby cynowe miały „iść w równy dział"195. Inna „szlachetna" Zofia z Sulmowskich, wdowa po Janie Mikołajowskim (województwo kaliskie), podzieliła między dziedziców ojcowską „cynę herbową” (1636) ${ }^{196}$.

Rozmaitość posiadanych przedmiotów wykonanych z cyny przedstawił $\mathrm{w}$ testamencie spisanym w dobie moru (zdążył już stracić żonę i córkę, kolejna córka walczyła z chorobą), Stanisław Bielczewski z województwa kaliskiego (1639). Sreber miał niewiele, żadnej zastawy stołowej. Tymczasem jedna ze szkatuł była wypełniona cyną „,do wierzchu”. Leżało tu talerzy dwanaście, półmiski (,na jednych są herby moje, ale na drugich nie masz”), misy, przystawki, niecki do mięsa, „kufel z przykrywką angielski” (być może z angielskiej cyny), konwie, solniczki. Inne rzeczy cynowe Bielczewskiego to flasze, lichtarze różnej wielkości, w tym jeden z „rogami”, wreszcie „miednica rzezana [rytowana - A.K] z nalewką”. Do tego „miednica wielka i nalewka z osobna" 197 .

Równie kompletny zestaw cyny stołowej; po jednym puzdrze talerzy i mis wielkich, półmisków 4 puzdra, konwie dwie (jedna o pojemości trzech, druga — jednego garnca), solniczka, do tego nalewka i miednica, wyliczono w inwentarzu stanowiącym część testamentu Piotra Niniewskiego z województwa kaliskiego ${ }^{198}$. Ważne elementy szlacheckiej zastawy, naczynia do mycia rąk, sprzęt oświetleniowy, były wykonane z cyny. O miednicach srebrnych wspominają tylko trzy testamenty ${ }^{199}$.

W testamentach wielkopolskich, częściej niż w pochodzących z Prus, wspominano o paradnej broni, zwłaszcza białej, oprawnej w srebro (niekiedy złocone) — o szablach ${ }^{200} \mathrm{i}$ koncerzach $^{201}$. Trafia się nie wspominany w Prusach kord ${ }^{202}$, lub laska trzcinowa „,srebrem oprawna”"203. Podobnie nieco częściej testatorzy dysponowali bronią palną zdobioną srebrem (rusznice pta$\mathrm{Sze}^{204}$, pistolety ${ }^{205}$ ). Więcej uwagi zwracano także na elementy rzędu końskiego ${ }^{206}$.

Wśród militariów notowano także rzeczy wyraźnie mające dla testatora wartość nie tylko użytkową i materialną, ale też emocjonalną, prestiżową, zabytkową. Przykład szedł zresztą z góry, z samych szczytów drabiny społecznej. Zgodnie z kolejnymi testamentami Zygmunta III Wazy każdy z jego synów otrzymywał od ojca paradna szpadę (król hołdował modzie zachodniej). Np. dla Jana Kazimierza w akcie ostatniej woli z roku 1623 została przeznaczona szpada „która została nam podarowana przez najjaśniejszego rodzica naszego, została przerobiona na nasz pierwszy ślub wedle nowego zwyczaju, przyozdobiona drogimi kamieniami i perłami”"207.

192 Testamenty. 2008, nr 53.

193 Testamenty. 2008, nr 40, 53.

194 Testamenty. 2008, nr 11, 19, 40, 42, 53.

195 Testamenty. 2008, nr 11, 1633, s. 42-43.

196 Testamenty. 2008, nr 19, 1636, s. 56.

197 Testamenty. 2008, nr 40, ok. 1639, s. 90.

198 Testamenty. 2008, nr 42, 1641, klient Leszczyńskich(?), prawnik(?).

199 Testamenty. 2008, $\mathrm{nr} 42,53,87$.

200 Testamenty. 2008, nr 6, 40, 47, 49, 71.

201 Testamenty. 2008, $\mathrm{nr}$ 6, 53, 59.

202 Testamenty. 2008, $\mathrm{nr} 40$.

203 Testamenty. 2008, $\mathrm{nr} 42$.

204 Testamenty. 2008, nr 40, 53.

205 Testamenty. 2008, nr 53.

206 Testamenty. 2008, nr 6, 53, 59.

207 Testamenty Zygmunta III Wazy. 2013, s. 108. 
To pełna synteza wartości materialnej, wymogów mody, emocjonalnego stosunku do ojcowskiego dziedzictwa i własnych wspomnień. W tej sytuacji nie dziwi, że Stanisław Rokossowski, posesjonat (?) zapewne niewielki, za to bardzo sobie ceniący kontakty z możniejszymi, w testamencie z roku 1645, przekazał synowi Krzysztofowi, oprócz kilku innych cennych przedmiotów („,czaprag na aksamicie haftowany, konew wielka srebrna z herbem królewskim i nieboszczyka pana wojewody łęczyckiego, rusznice ptasze w srebro oprawne, zegarek gładki złoty, pacierze [...] koralewe, koc angorski czerwony”), dwa obrazy o treści religijnej (jeden to ikona moskiewska), janczarkę [strzelbę - A.K.] „turecką którąśmy z chocimskiej wojny z sobą przywieźli” oraz ,szablę czerkieską w białey oprawie, którąmem miał od nieboszczyka Pana krajczego dobrodzieja mego, a on ją miał za wielki upominek od nieboszczyka Pana starosty halickiego Strusia a on zaś miał od sołtana Dewlet Gereja, tego, co hetmany na Cecorze gromił, że od tak wielkich ludzi wyszła i on to niech ma za klejnot" [podkr. — A.K. $]^{208}$. Temuż Krzysztofowi ojciec zapisał „księgi theatrum urbium” - dzieło o charakterze encyklopedycznym ${ }^{209}$.

Charakterystyka poszczególnych przedmiotów, ich wartości, wagi, wielkości, konstrukcji, wyglądu (w tym zdobienia) jest równie lakoniczna jak w materiale pruskim. Do najbogatszych w szczegóły należy oblatowany w roku 1646 w grodzie wschowskim testament Samuela z Mielęcina Mielęckiego, pana na dwóch wioskach i trzech folwarkach, ale zarazem dworzanina królewskiego. Z klejnotów posiadał „różę złotą rubinami sadzoną” wartości 1000 fl. i łańcuch „W włoskie koła” za 145 fl. Za część sreber, które odziedziczył po bracie komorniku kaliskim, po wykupieniu ich z zastawu i sprzedaży złotnikowi we Wschowie uzyskał łącznie 289 zł $25 \mathrm{gr}$. Tyle były warte: konewka z czterema kubkami, 2 paski i połamane łyżki ${ }^{210}$. W dołączonym do jego testamentu inwentarzu ruchomości część pierwszą stanowi spis klejnotów z wyceną każdego w złotych. Ogółem określono je na 5435 zł. W regestrze srebra stołowego, obok zastawy, uwzględniono też sztućce, naczynia kuchenne, lichtarze, części rzędu końskiego i broń (koncerz wart 300 fl.). Wszystkie srebra oszacowano na 3700 fl. Podano też ich wagę w grzywnach i skojcach. Listę otwiera miednica z nalewką srebrną złocistą trybowana; waga kruszcu to 2 grzywny 7 skojców, wartość 736 fl. Poszczególne naczynia były pozłacane lub nie, zdobione trybowaniem (,tribowana robota”) - miednica, kufel, koneweczka, puchar, solniczka, lub rytowaniem (,rysowana robota”) — kufel. Wspomina się też ośrodki produkcji — robota: „tuszporska”211.

O wartości klejnotów, tym razem wyrażonej w czerwonych złotych, dowiadujemy z także z inwentarza stanowiącego część testamentu wspominanego Piotra Niniewskiego. Jego własnością był łańcuch złoty, z popularnym — jak się wydaje — motywem kół młyńskich, ważący „trzydzieści czerwonych złotych i półczwarta”212.

Wzmianki o luksusowych ubiorach zawiera ok. 40\% testamentów szlachty wielkopolskiej ze zbioru obejmującego lata 1631-1655 (40 ze 105) i zaledwie ok. 1/5 aktów ostatniej woli z lat 1657-1700 (80 na ogółem 386) 213 .

${ }^{208}$ Testamenty. 2008, nr 49, s. 105-107. Podobnie cenili ojcowski oręż najwięksi magnaci z innych prowincji Korony. Podkanclerzy Tomasz Zamoyski, w testamencie z roku 1633, powierzył synowi: ,[...] rząd zloty dyjamentami sadzony, zupełny, z szablą takąż”, zastrzegając „,aby to przy nim samym zostawało”, Testamenty. 2007, s. 81-82.

209 Testamenty. 2008, nr 49, 1645, s. 105-107.

210 Testamenty. 2008, nr 53, 1645, s. 112-117.

211 Testamenty. 2008, nr 53, s. 114-115.

212 Testamenty. 2008, nr 42, s. 96-97, tu waga, cena i pojemność także innych przedmiotów.

${ }^{213}$ W okresie bezpośrednio po najeździe szwedzkim (1657-1680) wśród 201 testamentów odzież luksusową notuje 40 aktów (Testamenty. 2011); wśród 185 testamentów z lat 1681-1700 (Testamenty. 2015) także 40; w każdym z przypadków ok. 1/5 ogółu. 
W latach 1631-1655 wśród odzieży wierzchniej najliczniej, bo każdym przypadku w kilkunastu testamentach, wzmiankowano szaty tradycyjne - modne już w XVI w. ferezje ${ }^{214}$, dołomany ${ }^{215}$, delie ${ }^{216}$. Świetną, podszytą złotogłowiem, aksamitną ferezję zapisał kaliskim bernardynom jednowioskowy posesjonat, pan na Dembym, Kazimierz Władysław Mikołajewski $(1655)^{217}$. Przynależne do kształtującego się właśnie szlacheckiego (polskiego) ubioru narodowego kontusze i żupany spisano w mniejszej liczbie dokumentów. Kontusz tylko w kilku ${ }^{218}$, począwszy od roku 1646. Dworzanin królewski, Samuel Mielęcki, ofiarował synowi Konstantemu wśród szat jedwabnych - oprócz 6 ferezji — także 2 kontusze (czarny aksamitny, podszyty rysiami, z sześcioma złotymi guzami z rubinami, drugi również czarny tabinowy, z pętlicami czarnymi jedwabnymi ${ }^{219}$. Wcześniej (już w latach trzydziestych) i w większej liczbie aktów ostatniej woli (ogółem 14) wymieniano żupany ${ }^{220}$. Ostatnim elementem stroju, często wzmiankowanym, były nakrycia głowy: czapki ${ }^{221}$, kołpaki ${ }^{222}$, wyjątkowo kapelusze ${ }^{223}$. Wśród tkanin, z których były wykonane okrycia, dominował atłas (17 testamentów) ${ }^{224}$, adamaszek (12 testamentów) $)^{225}$ i aksamit (7 testamentów) ${ }^{226}$. Rzadziej do ich uszycia używano tabin ${ }^{227}$ i złotogłów ${ }^{228}$. Wśród zdobiących lub ocieplających ubiory luksusowych futer posiadano sobole $^{229}$, znacznie rzadziej rysie ${ }^{230}$, gronostaje ${ }^{231}$, popielice ${ }^{232}$. Przekazywano także odzież z tańszymi futrami - lisami ${ }^{233}$ lub wilkami ${ }^{234}$.

Typowy jest się zapis Jana z Marzelewa Noskowskiego, szlachcica jednowioskowego [? - A.K.], w księgach pyzdrskich (1652). Oprócz gotówki, sreber, bydła i owiec, rozdzielił swoje cenne szaty. Bernardynom na fundację nowego konwentu w Podgórzu [pod Toruniem? — A.K.] ofiarował: „Ferezyją aksamitną sobolami podszytą ze wszytkimi u niej będącymi potrzebami”, bratu Stanisławowi „ferezyją szkarłatną rysiami podszytą z guzami i ze wszytkimi potrzebami, do tego żupan atłasem wiśniowy i czapkę aksamitną czerwoną z sobolem, wyłogami [...] i ferezyją półgranatnią lampartowym aksamitem podszytą”. Bratanek Samuel miał dziedziczyć: ,delikę aksamitną czerwoną pupkami podszytą z guzami złotymi dyjamentami sadzonymi, także żupan szkarłatny jedwabny z guzami [...] srebrnymi złocistymi, do tego czapkę aksamitną szkarłatną i katunkę adamaszkową [...]". Brat testatora, Marcjan, otrzymał ubiór skromniejszy — „kontusz zielony falendyszowy lisami [tylko?! — A.K.] podszyty z guzami srebrnymi złocistemi, także delijke purpurową nową i czapkę aksamitna marmurkową"235.

214 Testamenty. 2008, nr 1, 5, 6, 31, 41, 42, 53, 57, 60, 61, 68, 71, 74, 77, 85, 87, 104, 105.

215 Testamenty. 2008, nr 4, 6, 7, 8, 25, 28, 30, 31, 36, 39-42, 61, 77.

216 Testamenty. 2008, nr 1, 4, 8, 28, 30, 31, 39, 40-42, 57, 60, 61, 66, 68, 77, 85, 87.

217 Testamenty. 2008, nr 105, 1655, s. 202.

218 Testamenty. 2008, nr 53, 57, 71, 81, 101.

219 Testamenty. 2008, nr 53.

220 Testamenty. 2008, $\mathrm{nr} 8,41,44,53,7,60,68,71,77,81,83,87,101,104$.

221 Testamenty. 2008, nr 11, 28, 69, 71, 78, 87, 89, 101.

222 Testamenty. 2008, nr 4, 8, 39, 40, 42, 53, 57, 104.

223 Testamenty. 2008, nr 40, kapelusze dwa „paniej”, s. 89.

224 Testamenty. 2008, nr 1, 5, 6, 8, 40, 44, 53, 54, 57, 60, 61, 71, 74, 78, 81, 101, 104.

225 Testamenty. 2008, $\mathrm{nr}$ 1, 5, 6, 39, 40, 42, 44, 54, 61, 85, 87, 104.

226 Testamenty. 2008, nr 40, 53, 57, 60, 87, 101, 105.

227 Testamenty. 2008, nr 53, 57, 71, 101.

228 Testamenty. 2008, $\mathrm{nr} 5,105$.

229 Testamenty. 2008, nr 8, 40, 42, 53, 57, 60, 61, 71, 77, 78, 87, 89, 104.

230 Testamenty. 2008, nr 5, 53, 60, 77, 87.

231 Testamenty. 2008, nr 40.

232 Testamenty. 2008, nr 60.

233 Testamenty. 2008, nr 39, 53, 54, 57, 60, 77, 85, 87.

234 Testamenty. 2008, nr 42, 60, ,wilczura”.

235 Testamenty. 2008, nr 87, 1652, s. 176. 
Znacznie rzadziej w analizowanych źródłach wymieniano cały zestaw ubiorów kobiecych. Do wyjątków należą dwa akty. W pierwszym Zofia Wolska, szlachetna żona młynarza Michała z okolic Wałcza (primo voto za szlachetnym Wojciechem Wolskim) rozdysponowała następujące damskie stroje: „suknię falendyszowa brunatną”, mętlik czarny sukienny, ,szubkę czarną futrem lisiem podszytą” „czapkę czarną aksamitną bobrową”, „,mętliczek kitajczany gardłami kunemi podszyty".

Obok atrybutów szlacheckiego luksusu, np. jedwabiów, w użyciu był solidny, choć dostępny też dla plebejów, falendysz, zaś z futer - bobry, kuny, lisy ${ }^{236}$.

Drugi testament, oblatowany w księgach kaliskich w dobie zarazy przez wspominanego Stanisława Bielczewskiego ${ }^{237}$, sporządzony bezpośrednio po śmierci żony i jednej z córek testatora, w nadziei na przeżycie własne i przebywających poza Kaliszem synów, zawierał również rozporządzenia odnośnie do ubrań, bez wątpienia luksusowych. Oprócz innych ruchomości męskim potomkom miało przypaść „Ubranie paniej”, w tym „Czamara kanafajowa z kołnierzem gronostajowym, pluszczyk [płaszczyk - A.K.] czarny z felpią i kapelusze dwa, czapeczka czarna $[\ldots]$ i zielona”, ,inderak ${ }^{238}$ brotny [z] jedwabnego muchajeru, inderak zielony muchajerowy, inderak szydzierzowy, rękaw kanafajowy", dalej suknie: adamaszkowa, atlasowa, kanafajowa, kitajkowa; 3 kolejne inderaki (turecki, muchajerowy, powszedni), „czamara łajewa futrem nowogrodowym”, dwa kożuchy, „nowy płaszczyk czarny aksamitny”, „mętliczek czerwony aksamitny, metlik turski muchajerowy gronostajmi podszyty, płaszczyk czarny w kostkę zieloną felpą, płaszczyk Marysi zieloną felpą, suknia łuzarowa muchajerowa Marysina, suknia brunatna muchajeru jedwabnego Marysina".

Lata 1657-1700 przyniosły istotną zmianę w asortymencie odzieży, którą dysponowali wielkopolscy testatorzy. Bardzo rzadko wspominano o deliach ${ }^{239}$, wyjątkowo o ferezjach ${ }^{240}$, czy dołomanie $^{241}$. Standardem, wśród szczegółowych zapisów dotyczących tekstyliów, były dary kontuszów i żupanów. Te pierwsze wymieniono w 40 analizowanych dokumentach ${ }^{242}$, te drugie zaś w $34^{243}$. Spośród innych elementów ubioru przedmiotem dość licznych zapisów testamentalnych były czapki (26 testamentów) ${ }^{244}$. Do sporadycznych należą informacje o innych nakryciach głowy, np. kołpaku ${ }^{245}$. W kilku testamentach odnotowano pasy ${ }^{246}$. Wyjątkowo zapisywano ubiory cudzoziemskie, takie jak aksamitny, podszyty lisami szustokor ${ }^{247}$, albo należąca do zmarłej w 1694/1695 r. Teresy z Tomickich Gadkowskiej „,brandenbura czarna chatłasowa letnia z guzami"248. Z ubiorów kobiecych wzmiankowanych rzadko, bo tylko w 8 testamentach,

${ }^{236}$ Testamenty. 2008, nr 11, 1633, s. 43. O aksamicie i adamaszku jako atrybutach szlacheckości nawet w surowym środowisku protestantów, por. Żołądź-Strzelczyk D. 2009, s. 120.

237 Testamenty. 2008, nr 40, 1639, s. 89-90.

238 Marszczona spódnica lub suknia, Turnau I. 1999, s. 72.

239 Testamenty. 2011, nr 69, 110.

${ }^{240}$ Najpóźniejsza wzmianka pochodzi z roku 1670, z testamentu Marcina Napruszewskiego, burgrabiego ziemskiego kaliskiego, szlachcica kilkuwioskowego, który zapisał żonie „ferezję rysią”, Testamenty. 2011 , nr 110.

241 Testamenty. 2011, nr 69.

${ }^{242}$ Testamenty. 2011, nr 9, 29, 51, 68, 73, 79, 83, 96, 100, 107, 110, 117, 133, 134, 140, 141, 161, 171, 178, 187, 194, 197, 201; Testamenty. 2015, nr 15, 23, 27, 31, 32, 58, 64, 68, 73, 90, 97, 110, 124, 126, 131, $162,173$.

${ }^{243}$ Testamenty. 2011, $\mathrm{nr} 9,29,51,56,73,79,83,98,100,107,110,111,129,134,140,171,183,194,201$; Testamenty. 2015, nr 15, 23, 31, 58, 64, 68, 69, 90, 95, 96, 97, 104, 113, 142, 162.

${ }^{244}$ Testamenty. 2011, nr 28,29, 51, 56, 69, 73, 79, 110, 141, 151, 180, 190, 201; Testamenty. 2015, nr 15, 23, 29, 31, 34, 69, 77, 101, 104, 111, 112, 162, 173.

245 Testamenty. 2011, nr 110.

246 Testamenty. 2011, nr 51, 56, 73, 101; Testamenty. 2015, nr 68, 90, 143.

247 Testamenty. 2011, nr 197, s. 338.

${ }^{248}$ Brandenbura, według Turnau I. 1999, s. 28: ,suknia zimowa lub okrycie damskie zdobione pasmanterią, noszone w XVII/XVIII w., Brandebourgs, modne wówczas we Francji rzędy pętlic w mundurach i ubiorze cywilnym", Testamenty. 2015, nr 147, s. 346. 
wspomniano o spódnicy [spodniku - A.K.] ${ }^{249}$, zaś w pojedynczych przypadkach o sukniach, takich jak alamoda 250 i manta (suknia lub płaszczyk) ${ }^{251}$.

Choć zmieniły się rodzaje ubiorów, to zdecydowaną większość stanowiły kontusze i żupany. Nie uległy natomiast zmianie stosowane do ich wykonania materiały: tkaniny i futra, nadające im luksusowy charakter. Wśród tekstyliów także w drugiej połowie XVII w. przeważały jedwabie (bławaty), a wśród nich atłas (26 testamentów) ${ }^{252}$ i aksamit (16 testamentów) ${ }^{253}$. Znacznie mniej testatorów niż w pierwszej połowie stulecia wspominało o wyrobach z adamaszku, tylko pięciu ${ }^{254}$. Wśród wzmiankowanych tkanin częściej natomiast spisywano kitajkę (13 testamentów $)^{255}$. Podobnie jak przed Potopem, rolę drugorzędną wśród notowanych w testamentach ubiorów, odgrywały te wykonane z tabinu (10 testamentów $)^{256}$, czy z innych tkanin jedwabnych importowanych z Włoch — tercyneli ${ }^{257}$ i telety ${ }^{258}$. Wśród zapisywanej odzieży trafiały się także wykonane z materiałów naśladujących jedwab, takich jak brokatela [burkatela-A.K.]. W roku 1698 Jakub Chmieleński, szlachcic jednowioskowy z Kaliskiego, oprócz nieruchomości, zapisał dzieciom także odzież, w tym córkom ubiory po żonie — kierejkę brukatelową w kwiaty złociste, podszytą popielicami oraz takąż sukienkę podszytą lisem ${ }^{259}$.

Nieodłącznym elementem luksusowej odzieży były także najcenniejsze futra/skóry, niekiedy używane jako podszycie, dodatek do stroju. Podobnie jak w pierwszej połowie stulecia najczęściej wspominano o sobolowych futrach (26 testamentów) ${ }^{260}$. Z soboli szyto przede wszystkim czapki ${ }^{261}$. Cenne futro łączono z tkaninami. Jadwiga z Rechwiczów Czeluścińska zapisała wnuczce Zofii krymkę [czapkę z płaskim dnem - A.K.], ,aksamitną, karmazynową z sobolem"262. Jakub Chmieleński, szlachcic jednowioskowy z kaliskiego (1698), zapisał synowi Ignacemu czapkę sobolową z wierzchem szkarłatnim ${ }^{263}$. Marcin Lubiatowski, posesor czterech wsi w Kaliskiem, przekazał córce Katarzynie, prócz różnych ubrań także „czapek sukiennych sobolcowych dwie, z których jedna nowa, druga stara" ${ }^{264}$. Cenione były nawet sobole mocno już zużyte. Jeden z testatorów zobowiązał małżonkę, aby zachowała i w odpowiednim czasie przekazała synowi różne ruchomości po ojcu, w tym „czapkę sobolikową już natartą"265. Najzamożniejsi nosili czapki sobolowe zdobione drogimi kamieniami. Zmarły w 1686 r. Andrzej Smoszewski, starosta bobrownicki, właściciel miasta Więcborka oraz wsi w powiatach nakielskim, kcyńskim i lipnowskim, „naznaczył” córce „,czapkę sobolcową z igrzyskami

249 Testamenty. 2011, nr 28, 108, 149, 197; Testamenty. 2015, nr 34, 63, 108, 173.

250 Testamenty. 2011, $\mathrm{nr} 28,108$.

251 Testamenty. 2015, nr 114, 147.

${ }^{252}$ Testamenty. 2011, nr 28, 56, 70, 96, 100, 107, 110, 138, 171, 183, 187, 201; Testamenty. 2015, nr 31, $34,63,64,69,90,95-97,111,114,142,147,173$.

${ }^{253}$ Testamenty. 2011, nr 29, 56, 73, 101, 110, 117,164, 178, 180, 201; Testamenty. 2015, nr 31, 64, 73, 108, $110,173$.

254 Testamenty. $2011 \mathrm{nr} 83,180$; Testamenty. 2015, nr 90, 124, 162.

255 Testamenty. 2011, nr 56, 83, 98, 108 129, 187; Testamenty. 2015, nr 15, 3, 64, 68, 69, 114, 147.

256 Testamenty. 2011, nr 100, 101, 180, 190; Testamenty. 2015, nr 34, 63, 99, 108, 114, 173.

257 Testamenty. 2011, nr 101; Testamenty. 2015, nr 31, 64.

258 Testamenty. 2015, nr 34.

259 Testamenty. 2015, nr 173, s. 397. Brokatela, brukatela - wzorzysta tkanina półjedwabna, rzadziej lniana, importowana z Hiszpanii i Włoch, zwłaszcza z Wenecji; w drugiej połowie XVII w. produkowana też w Polsce jako tkanina półwełniana, drukowana we wzory kwiatowe, naśladująca jedwabie, Turnau I. 1999, s. 29.

${ }^{260}$ Testamenty. 2011, $\mathrm{nr} 51,56,69,73,99,110,117,141,151,180,201$; Testamenty. 2015, nr 15, 23, 29, $31,34,58,64,68,77,108,111,112,162,173,184$.

${ }^{261}$ Np. Testamenty. 2011, nr 56, 69, 73, 99; Testamenty. 2015, nr 29, 31, 69,77, 104, 111, 112, 162, 184.

262 Testamenty. 2015, nr 108, 1690, s. 269.

263 Testamenty. 2015, nr 173, 1698, s. 397.

264 Testamenty. 2015, nr 15, 1680, s. 68.

265 Testamenty. 2015, nr 162, 1696, s. 377. 
diamentow(e)y"267. Sobole używano do dekoracji i ocieplenia nakrycia głowy. Nieczęsto wspominano o nich, że nadają się do dalszej obróbki ${ }^{267}$, do podszycia lub obszycia ${ }^{268}$, wreszcie, że mają postać kołnierza, np. przy kontuszu ${ }^{269}$. Rzadziej niż sobole w testamentach odnotowywano inne luksusowe futra - rysie $(18 \text { aktów })^{270}$, popielice $(11 \text { testamentów })^{271}$ bądź wyjątkowo gronostaje $^{272}$. Rysie to futra (wyprawione ?) ${ }^{273}$, częściej — grzbiety i nóżki używane do podszycia kontusza ${ }^{274}$. Piotr Kobierzycki, dziedzic wsi Rajsko w powiecie kaliskim, zapisał synowi Franciszkowi „kontusz rysiami podszyty gryszpanowy”. W istocie jednak z cennego ubioru skorzystało kilkoro spadkobierców. Rysie spod kontusza przypadły wspomnianemu Franciszkowi, zielona wierzchnia tkanina (gryszpan) córkom (nie wiemy w jakiej liczbie), zaś 6 guzów rubinowych drugiemu synowi testatora - Remigiuszowi ${ }^{275}$. W testamentach wspominano nie tylko rysie nowe, w dobrym stanie. W ostatniej woli jednowioskowego posesjonata, Jakuba Chmieleńskiego, synowi Ignacemu dostał się kontusz granatowy „rysiami podszyty nienowemi”"276. Podobną rolę — podszycia kontusza, np. szczególnie cennego — ślubnego ${ }^{277}$, pełniły popielice ${ }^{278}$. Podbijano nimi także inne ubiory, np. kobiecą kiereję ${ }^{279}$. W testamentach zamieszczano także dane o futrach bardziej pospolitych, tj. lisich ${ }^{280} \mathrm{i} \mathrm{kunich}^{281}$.

Typowy, w miarę pełny zestaw cennej wierzchniej garderoby cząstkowego posesjonata, zawiera testament Wojciecha Bartoszewskiego (1682). Swojemu imiennikowi, synowcowi Wojciechowi, przeznaczył „kontusz sukienny grzbietami rysiemi podszyty, kontusz czarny tercjanelowy kitajką podszyty, żupan atłasowy szkarłatny”. Drugi synowiec - Jędrzej miał otrzymać kontusz czarny, aksamitny „nóżkami rysiemi podszyty, kontusz tercjanelowy błękitny pupkami podszyty i czapkę sobolową [...]. Córka bratanka testatora, Zofia Bartoszewska, obdarowana została „,kontuszem slamami podszytym”282. Zupełnie inny jest testament magnata, właściciela ośmiu kluczy dóbr w różnych częściach Wielkopolski, podstolego koronnego, Stefana Adama Grudzińskiego. Integralną część tego aktu stanowi inwentarz („Regestr rzeczy spisanych w skarbcu złotowskim") ${ }^{283}$. Obok sreber, cyny, broni (białej i palnej), rzędów końskich, obić, obejmuje także odzież, w tym po 10 kontuszy i żupanów, 4 kaftany, 2 kiereje. Kontusze i żupany uszyte były z atłasu, aksamitu, ale także z tkanin bawełnianych i z sukna. Te ostatnie miały podszewki z różnych tkanin jedwabnych lub półjedwabnych (kitajka, lama, tercanela).

266 Testamenty. 2015, nr 77, s. 198.

${ }^{267}$ Według testamentu Marianny z Pierskich, jej córki miały podzielić się futrem rysim, trzema bretami ogonków i sobolem jednym (Testamenty. 2015, nr 34, 1862, s. 100). Podstoli koronny, Stefan Adam Grudziński, rozdysponował „Sztukę soboli. Soboli dwa” (Testamenty. 2015, nr 64, 1684, s. 165).

268 Testamenty. 2011, nr 117.

269 Testamenty. 2015, nr 58, 1685, s. 145.

270 Testamenty. 2011, nr 56, 73, 83, 100, 107, 110, 164, 175, 178, 201; Testamenty. 2015, nr 31, 68, 69, 73, 90, $131162,173$.

${ }^{271}$ Testamenty. 2011, nr 28, 37, 79, 96, 110, 141, 180; Testamenty. 2015, nr 15, 124, 126, 173.

272 Testamenty. 2015, nr 108.

273 Np. Testamenty. 2011, nr 175; Testamenty. 2015, nr 69.

${ }^{274}$ Np. Testamenty. 2011, nr 56, 10; Testamenty. 2015, nr 31, 68, 73, 90, 131, 162, 173.

275 Testamenty. 2015, nr 68, 1686, s. 175.

276 Testamenty. 2015, nr 173, 1698, s. 397.

277 Testament 2011, nr 79.

278 Testamenty. 2011, nr 28, 37, 96, 141; Testamenty. 2015, nr 15, 23, 124, 126.

279 Testamenty. 2015, nr 173, 1698, s. 397: „kierejka burkatelowa w kwiaty złociste popielicami podszyta” należała do żony wspomnianego powyżej Jakuba Chmieleńskiego.

280 Testamenty. 2011, nr 96, 108; Testamenty. 2015, nr 69.

281 Testamenty. 2011, nr 28.

282 Testamenty. 2015, nr 31, 1682, s. 93-94.

283 Testamenty. 2015, nr 64, s. 164-166, testament - 1685 r., regestr ruchomości - 1684 r. 
Część kontuszy była podszyta lub bramowana („opuszona”) cennymi sobolami ${ }^{284}$. W przypadku innych tańsze bywało ocieplenie, droższe ozdoby. W kontuszu tercanelowym [jedwabnym —A.K.] ,jonotami podszytym, sobolami opuszonym” sobole zostały użyte jako obramowanie, element ubioru rzucający się w oczy, zaś jonoty — skóry z kotów importowane ze Wschodu (Chiny, Rosja) lub z jenotów - stanowiły właściwe, mniej eksponowane podszycie ${ }^{285}$. Inny kontusz Grudzińskiego, wykonany z nieznanej tkaniny, był podszyty białymi królikami, ale ozdobiony (opuszony) sobolami ${ }^{286}$. Oprócz części odzieży, w regestrze odnotowano także futra wyprute z szat oraz wyprawione i jeszcze nie wykorzystane, tj. sobole, gronostaje, wilki, jelenie, ,jąnoty"287.

Poza szatami wierzchnimi, w rejestrze rzeczy będących własnością Grudzińskiego, odnotowano także kosztowne do nich dodatki, przede wszystkim jedwabne pasy (,turecki biały z kwiatami złotem i jedwabiem szyty”, „biały wielki wszytek srebrem i zlotem jedwabiem szyty”), poza tym bieliznę — koszule (,kitajkowa turecka”) i chustki, w tym także z jedwabiu, wyszywane nićmi srebrnymi i złotymi. W zestawieniu uderza brak nakryć głowy, jedynie „czapka fioletowa z opuszką łabędziową”. Część ubrań była jednak świadomie pominięta. Świadczy o tym adnotacja: „Testamentczyk ja drugi wszytkich rzeczy i klejnotów, które z sobą biorę, uczynię w drodze"288. Niestety tego równie ważnego zestawienia brakuje.

W testamentach z M ało p o l s k i obok precjozów znanych także w Prusach i Wielkopolsce pojawiają się przedmioty na zachodzie Rzeczypospolitej nie notowane. Aleksander Ankwicz, komornik ziemski pilzneński (1692), nakazał kupić mszał dla kościoła frysztackiego, zaś na jego oprawę przerobić „kusz srebrny [naplecznik zbroi? - A.K.] [...] od hajduckiej sukni”. Dla swej małżonki przeznaczył, wśród innych sreber, również „czarkę [...] wewnątrz pozłocistą, od wódki" ${ }^{289}$. Wyroby te wymieniano też w aktach ostatniej woli z innych prowincji, jednak tu nowością jest sprecyzowanie ich funkcji. Coraz popularniejsza i ceniona jako używka wódka doczekała się więc specjalnych naczyń, z których trafiała do szlacheckich gardeł. Z kolei „Apteczką srebrną pokojową" obdarowała siostrę (krakowska klaryskę) Teofila z Tarłów Ostrogska (1635) ${ }^{290}$.

W analizowanych dokumentach uwzględniano także specyficzne srebra, stanowiące część materialnej oprawy rytuału pogrzebowego. Stanisław Leszczyński, szlachcic z Sądeckiego (1687), polecił z łyżki i dwóch srebrnych kubków zrobić „tablicę srebrną z herbami mojemi”. W czasie nabożeństwa pogrzebowego miała być ona przybita „w głowy” trumny, potem zaś miała trafić na wieczne czasy do kościoła franciszkanów w Nowym Sączu. Tam (zapewne wraz z innymi wotami) miała zdobić obraz „oblicza pańskiego”. Bardziej urozmaicony niż na zachodzie Korony wydaje się też asortyment przekazywanej, oprawnej w srebro broni, np. pałasz, z wyposażenia — sajdak ${ }^{291}$.

Jak wszędzie, tylko wyjątkowo testatorzy szerzej opisywali konkretne przedmioty, podając wagę kruszcu, wartość w pieniądzu. Np. Jan Podleski z okolic Biecza (1675) darował żonie strzelbę i „rządzik”, kosztujące 110 zł, natomiast pałasz „na którym srebra jest grzywien 4 i skojców 4" oddał synowi ${ }^{292}$. Od Aleksandra Ankwicza „łańcuszek złoty mający 20 czerwonych złotych" otrzymała panna Barbara Laskowska, z uwagi na przyjaźń testatora z jej ojcem ${ }^{293}$.

284 Np. kontusz izabelowy sukienny sobolami podszyty, Testamenty. 2015, nr 64, s. 164.

285 Turnau I. 1999, s. 75; Testamenty. 2015, s. 164.

286 Testamenty. 2015, s. 164.

287 Testamenty. 2015, s. 165: „Sobole do opuszenia tylko od kontusza czerwonego”, „,soboli dwa”, ,gronostaje z podkontusza złocistego”, ,Wilków wyprawnych siedem”, ,skór jelenich wyprawnych pięć”, ,jąnoty czarne”.

288 Testamenty. 2015, nr 64, s. 165-166.

289 Testamenty 1997, nr 10, 1692, s. 33-34.

${ }^{290}$ Cui contingit nasci. 2005, $\mathrm{nr} 23,1635$, s. 88.

291 Testamenty. 1997, nr 9, 1687, s. 26-27.

292 Testamenty. 1997, nr 6, 1675, s. 17.

293 Testamenty. 1997, nr 10, 1692, s. 32. 
Bogatsze w tego typu dane są niektóre testamenty z województwa sandomierskiego. Ze skromnego zestawu precjozów Zofii Gąszczyńskiej najcenniejszy był złoty łańcuch, którego sprzedaż przyniosła właścicielce ok. 210 zł. Pieniądze te rozeszły się „,na prawo, na doktory i na potrzeby" ${ }^{294}$. Z kolei prawie magnat, Hermolaus Ligęza, rozdziela w testamencie przede wszystkim wielkie i małe sumy, nie zaś konkretne przedmioty. Do wyjątków należy darowana synowcowi „na znak miłości” miednica wielka z nalewką srebrną ${ }^{295}$. O wartości ogólnej sreber informuje testament Teofili z Tarłów Ostrogskiej. Bratu i dalszym krewnym legowała dwie szkatuły sreber, za które zapłaciła odpowiednio 4000 i 1500 zł. Nie podano jednak, ile kosztowały umieszone w nich przedmioty — talerze, półmiski, misy, miednica z nalewką (gdańska) i lichtarze ${ }^{296}$. Takimi kompletami srebrnej zastawy z talerzami i miskami także w Prusach dysponowały tylko ścisłe elity ${ }^{297}$.

W badanych źródłach rzadko nadmieniano o rzeczach służących rozrywce, pracy intelektualnej lub fizycznej, uprawianemu hobby (?). Wojciech Młodawski, wspominany już, świeżo upieczony Prusak z Malborskiego, jednemu ze swoich nowych krajan zapisał m.in.: „warcaby [...] sadzone z kostkami wedle dawnej swej obietnicy towarzyskiej" $(1625)^{298}$. Być może z obdarowanym łączyła go przyjaźn z czasów służby w wojsku. Pisarzowi ziemskiemu pomorskiemu, Fabianowi Pisieńskiemu, dostały się natomiast księgi potrzebne w pracy urzędniczej. Młodawski zapisał mu „Statut łaciński Herbortów i Konstytucje Polskie"299.

Z kolei Hieronim Bystram, ze starej rodziny pruskiej (ojciec Fabian był sędzią ziemskim michałowskim), podarował wojewodzie inowrocławskiemu, Michałowi Działyńskiemu, weiderwerck oder miszlistwo. Zapewne obaj dzielili tę szlachecką pasję. Inny dar Bystrama - ein miezsch mit silber beschlagen otrzymał wojewoda malborski, Jerzy Kostka, prawdopodobnie miłośnik oręża ${ }^{300}$.

\section{Ruchomości w testamentach z Czech}

\section{Charakter informacji}

Kreśląc portret szlachty czeskiej u schyłku XVI w. Vaclav Bůžek scharakteryzował materialne atrybuty stanu szlacheckiego. Należało do nich m.in. posiadanie cennych, luksusowych ruchomości. Drobni rycerze żyjący na poziomie mieszczanina lub chłopa posiadali jeden lub dwa przedmioty ze szlachetnych kruszców (srebrne, pozłacane). Szlachta zamożniejsza, piastująca urzędy, miała ich wiele. Bůžek przytacza m.in. relacje z przyjęcia, jakie w latach dziewięćdziesiątych XVI w. wydał w swoim domu w Krumlowie Matyas Fuchs, urzędnik (dworzanin), a więc klient bądź familiant rezydującego w tamtejszym zamku jednego z najstarszych arystokratycznych rodów w Czechach — Rożmberków. Jedzenie podano na srebrnej zastawie (talerze, łyżki, widełki). Wina reńskie, węgierskie, włoskie trafiały na stół w konewkach, były zaś pite ze złotych lub pozłacanych pucharów i kubków. Stół zdobiły pozłacane wiatraki, tykwy, orzeszki muszkatołowe. Rodzina gospodarza wystąpiła w aksamitach, jedwabiach, wyszywanych złotą nicią czepcach. Nosiła także obfitą biżuterię: złote pierścienie z drogimi kamieniami, pasy, bransolety ${ }^{301}$.

W jakim stopniu zarysowany powyżej obraz mogą wzbogacić lub skorygować testamenty szlachty czeskiej? Pavel Král we wspominanym już kilkakrotnie opracowaniu całokształtu pro-

${ }^{294}$ Cui contingit nasci. 2005, nr 21, 1631, s. 80, konsystorz kurzelowski.

${ }^{295}$ Cui contingit nasci. 2005, $\mathrm{nr} 22,1632$, s. 85.

${ }^{296}$ Cui contingit nasci. 2005, nr 23, 1635, s. 87.

${ }^{297}$ Por.: Testamenty. 2008, nr 6 - Jan Konopacki, nr 29 - Dymitr Wejher.

298 Testamenty. 2008, nr 20, 1625, s. 116-117.

299 Testamenty. 2008, s. 117.

300 Testamenty. 2008, nr 3, 1608, s. 71, 73.

301 Bůžek V. 1995, s. 23. 
blematyki źródłoznawczej związanej ze szlacheckimi testamentami, kwestii uchwyconego w nich świata szlacheckich ruchomości nie stawia jednak w centrum, jest ona tylko jedną z wielu. Tym bardziej brakuje w jego rozważaniach miejsca na bliższą, może także statystyczną próbę opisania struktury ruchomości, kwestii luksusu, itp. Możliwość samodzielnego postawienia testamentom z Czech także takich pytań daje szczęśliwie druga, równie wartościowa jak źródłoznawcze wywody samego Autora, część książki Krála. Stanowi ją zbiór 101 testamentów ${ }^{302}$.

Czasami opis ruchomości ogranicza się do najogólniejszej formuły, obejmującej całość majątku ruchomego i nieruchomego (všelijaký [...] statek [...] movitý i nemovitý) ${ }^{303}$. Z zasady jednak testamenty informują także w sposób mniej lub bardziej lakoniczny o strukturze majątku, którym dysponowano. Wylicza się nadrzędne jego elementy, tzn. ruchomości (svršsi), klejnoty, dokumenty poświadczające własność (w tym listy dłużne, weksle), gotówkę ${ }^{304}$.

Niemal wszystkie testamenty zawierają dyspozycje dotyczące posiadanych pieniędzy. Wyjątek stanowi ostatnia wola szlachcica, Bernarda Hodejowskiego z Hodejowa $(1620)^{305}$. Synowcom testatora przekazano w spadku dokumenty i listy dłużne, brak zaś informacji o konkretnych sumach. Pozostałe akty ostatniej woli pełne są danych o liczonych w talarach, groszach miśnieńskich lub czeskich sumach wiennych należnych osieroconym małżonkom ${ }^{306}$, o dochodach zapisanych na konkretnych dobrach ziemskich ${ }^{307}$, wreszcie o kwotach przekazanych dzieciom i dalszej rodzinie. Typowy testament pozostawiła szlachcianka Kateřina Litochlebová z Malovic $(1600)^{308}$. Jej dzieci - Dawid i Ludmiła otrzymały po 300 kop groszy miśnieńskich, natomiast wnuczka (także Katarzyna) zapis długu - 100 kop miśnieńskich groszy, należnego testatorce od innego szlachcica.

Inna szlachcianka, Dorota Rochcová z Otova ${ }^{309}$, rozdysponowała sumy zapisane na dobrach ziemskich (1601), wynoszące łącznie 6200 kop groszy miśnieńskich. Przyjaciół i krewnych obdarowała sumami od 100 do 2000 kop. Na rzecz kościoła, w którym miała być złożona testatorka po śmierci, przeznaczono 60 kop. W dokumencie nie ma natomiast żadnej wzmianki o innych ruchomościach; wszystko jest przeliczone na pieniądze.

Podobna wycena dominuje w testamentach magnaterii (szlachty wyższej), choć sumy bywają większe. Świeżo upieczony arystokrata (podniesiony do stanu pańskiego w roku 1596), wcześniej rycerz, Kryštof Želinský ze Sebuzina, w testamencie z 1606 r. dysponował następującymi sumami: dla żony 12000 kop groszy miśnieńskich, każdej z dwóch córek jako wiano po 6000 kop, oraz dodatkowo po 1000 kop na wyprawę ${ }^{310}$.

Katolicki magnat, Václav Rozdražovský z Rozdražova ${ }^{311}$ cały majątek zapisał synom, zabezpieczył też wdowę i córki (1621). Te ostatnie otrzymać miały 5000 kop groszy miśnieńskich wiana oraz po 3000 kop groszy na wyprawę i koszty wesela. Wdowa zachować miała prawo do 10000 kop wiana oraz kolejnych 5000 zapisanych przez męża; pasierb na pamiątkę po ojczymie uzyskał 5000 kop. W dalszej części dokumentu zamieszczono listę legatów pobożnych na kościoły, szpitale, ubogich, alumnów, o łącznej wartości 5000 kop groszy miśnieńskich (poszczególne zapisy wynoszące od 500 do $1000 \mathrm{kop})^{312}$. Ta suma nie wyczerpuje jednak reli-

302 Král P. 2002, s. 106-559.

303 Testament szlachcianki Doroty Rochcovej (Král P. 2002, nr 52, 1601, s. 322). Podobnie szlachcianka, Zofia Břekovcová (Král P. 2002, nr 58, 1607, s. 351).

304 Np. Mikuláš z Bubna, Král P. 2002, nr 59, 1608, s. 356.

305 Král P. 2002, nr 71, 1620, s. 415-418.

${ }_{306}$ Král P. 2002, np. nr 49, 1600, s. 308.

307 Král P. 2002, np. nr 50, 1599, s. 314.

308 Král P. 2002, nr 51, 1600, s. 319-322.

309 Král P. 2002, nr 52, 1601, s. 322-325.

310 Král P. 2002, nr 57, s. 345.

311 Král P. 2002, nr 72, s. 418-429.

312 Král P. 2002, s. 422, 424. 
gijnej gorliwości testatora. Wsparcie w wysokości od 300 do 500 kop groszy miśnieńskich zyskało jeszcze z górą 20 praskich kościołów, klasztorów, szpitali, bractw pobożnych ${ }^{313}$.

Inny „pan” Jan Mikuláš Popel z Lobkowic nakazał synowi po osiągnięciu pełnoletności przekazywać matce, Ewie Euzebii, corocznie 500 kop groszy czeskich. Córki miały otrzymywać po 250 kop rocznie, a wiano każdej z ich przewidział w wysokości 500 kop groszy miśnieńskich, plus 250 kop groszy na wyprawę ${ }^{314}$. Małżonka uzyskała też zabezpieczenie na wypadek kolejnego zamążpójścia, lub ustania opieki nad najstarszym synem. Stanowiły je dwa domy w Pradze. Miały być jej własnością dziedziczną wraz ze wszelkimi, znajdującymi się w nich ruchomościami, jakkolwiek nie byłyby nazywane (jakýmikoli jmény jmenováno býti mohlo), w tym wyrobami ze złota i srebra, klejnotami, szatami, zasłonami (firhank), łożami, kobiercami, obiciami, stołami do pisania — biurkami (šrejbtis). Ten testator nie ograniczył się do zarządzeń w sprawie środków finansowych, lecz podał także kategorie mobiliów stanowiących wyposażenie jego praskiej kamienicy ${ }^{315}$.

Mniej lub bardziej szczegółowe opisy struktury części lub rzadziej całości majątku ruchomego zawiera mniej więcej połowa opublikowanych testamentów pańskich i $1 / 3$ rycerskich (szlacheckich).

Spośród magnatów, Jan z Vartemberka (1617), obok pieniędzy, klejnotów i wszelkich innych rzeczy, przekazał żonie Julianie własne szaty łożne (do spania), oraz vinuty (zawicia?) i chodici (szaty wierzchnie) ${ }^{316}$. Václav Obytecký z Obytec, w swoim rozporządzeniu majątkiem ruchomym (1648) uwzględnił gotówkę, klejnoty, łańcuchy złote, pierścienie, srebra, ubiory (chodici i vinuty), naczynia - cynowe, miedziane, drewniane, oraz dokumenty, zapisy, meble (sprzęty — nabytek), bydło (dobytek) i konie ${ }^{317}$.

Jan Jiří z Žegberka, dysponując posiadanymi ruchomościami (1639), wskazał zarówno ich kategorie (dokumenty, szaty, broń), grupy przedmiotów (siodła, rynsztunki, rusznice, pistolety, kordy; te dla czterech synów z pierwszego i drugiego małżeństwa), jak i pojedyncze rzeczy. Spośród szat wyróżnił płaszcze, jeden aksamitny czarny, drugi adamaszkowy, przeznaczone dla dwóch córek z pierwszego małżeństwa. Wszystkie cztery córki z pierwszego związku miały otrzymać na wspólną własność czepiec z perłami. Jeśli nie będą mogły nawzajem się spłacić, mogą czepiec sprzedać, a uzyskaną sumę podzielić318.

Bodajże najpełniejsze informacje o zestawie ruchomego mienia umieszczono w testamencie Anny Marii Šlikovej z Švamberka $(1615)^{319}$. Dwóm bratankom zapisała ona złoty łańcuch, srebra, kubki i naczynia do picia, natomiast czterem siostrzenicom pozostałe, różnorodne mobilia: łańcuchy, naszyjniki i bransolety, pierścienie, ozdobne klejnoty (geschmuck Cleinodien), suknie, pościel, płótno, len, przędze, owce, woły, jak również zboże w polu i stodole, wszelkie sprzęty domowe (Hausrath). Sześć koni zaprzęgowych oraz wozy (Wägen) i powozy (Kutschen) i wszystko co do nich przynależy, zgodnie z wolą Anny Marii miała otrzymać inna krewna — Sabina von Zedwitzs.

Generalnie, spośród opublikowanych przez P. Krála testamentów „pańskich” mniejszość stanowią te, w których zaprezentowano nieco dokładniej strukturę spisywanego majątku ruchomego, różne grupy współtworzących go dóbr. Zupełnie wyjątkowo testatorzy decydowali o losie poszczególnych przedmiotów.

Od tej normy nie odbiega też, opublikowany już w XIX w. testament jednego z największych magnatów sąsiednich Moraw, zarazem kardynała, księcia kościoła, biskupa ołomunieckiego,

313 Král P. 2002, s. 426-427.

314 Král P. 2002, nr 64, 1613, s. 381-389.

315 Král P. 2002, s. 385. O wyposażeniu innych siedzib Lobkowiców, por. Hrubá M. 2001, s. 77.

316 Král P. 2002, nr 68, 1617, s. 403.

317 Král P. 2002, nr 99, 1648, s. 533-535.

318 Král P. 2002, nr 90, 1639, s. 503.

319 Král P. 2002, nr 66, 1615, s. 392-399. 
Franciszka von Dietrichstein. Diecezją rządził w latach 1599-1636, zaś od roku 1621 pełnił z nadania cesarskiego urząd gubernatora i starosty krajowego Moraw (Landes Hauptman). W testamencie spisanym w grudniu 1634 r. w węgierskim Oedenburgu (Sopron) wielkie kwoty, sięgające po 50000 talarów, przekazał dziedziczącym jego majętności rodowe kuzynom i ich małżonkom. Zapisy pobożne pochłonęły z kolei ok. 6000 talarów. O innych ruchomościach napisano niewiele. Te tworzące majątek biskupa miały być sprzedane, a uzyskane pieniądza przekazane administracji diecezji; te zaś, które stanowiły część rodowej majętności kardynała, miały przypaść tym spośród jego krewnych, którzy będą partycypowali w kosztach pochówku. Szanse wejrzenia w otaczający biskupa świat rzeczy daje tylko sporządzony odrębnie rejestr wyposażenia biskupiej rezydencji (pałacu), który po inwentaryzacji miał pozostać na miejscu. Odpowiedni inwentarz stanowiący część testamentu obejmował m.in. wyposażenie kuchni i stołu na 12 osób. Zapewne w takim gronie spożywał biskup codzienne posiłki. W skład srebrnej zastawy wchodziło, oprócz miednicy z nalewką, 36 talerzy i tyleż mis ${ }^{320}$.

$\mathrm{Na}$ ile bogate $\mathrm{w}$ informacje o ruchomościach są testamenty szeregowej szlachty (stanu rycerskiego)? Z reguły reprezentanci tej grupy społecznej ograniczali się do stosowania ogólnej formuły, rozporządzając własnymi ruchomościami. Były one przeważnie przekazywane współmałżonkowi. Na taką testamentalną praktykę w Czechach wpływał zapewne przykład innych krajów niemieckich, w tym sposób rejestracji ruchomości w testamentach szlachty z Dolnej Austrii, graniczącego z Czechami dziedzicznego władztwa Habsburgów ${ }^{321}$.

Zwięzły w wyrażaniu swej ostatniej woli był Zdeněk Trmal z Toušic (1618), który cały majątek przekazał synowi, w tym sprzęty — meble, klejnoty, gotówkę, listy dłużne i przywile$\mathrm{je}^{322}$. Jan Bzenský przekazał nieruchomości i posiadane fundusze żonie i niepełnoletnim dzieciom (1619). Wspomniał także ogólnie o innych przedmiotach — wszelkich klejnotach złotych, srebrnych lub pozłacanych, złożonych w skrzynce i spisanych w inwentarzu, oraz o broni i szatach także zinwentaryzowanych. Inwentarze [nie wiadomo jednak czy zachowane - A.K.] być miały schowane u opiekunów wdowy i sierot, i stanowiły podstawę podziału tych rzeczy, gdy synowie Jana dorosną ${ }^{323}$. Wdowa, oprócz pieniędzy oraz wielu nieruchomości i praw (np. do korzystania z browaru i młyna), miała otrzymać wóz kryty i koni sześćc 324 . To jedyna ruchomość wspominana w tym testamencie.

Šebestián Ždárský325, zabezpieczając żonę i powierzone jej opiece sieroty (1628), przekazał wszelkie jej dobra, ,jakkolwiek by nie były nazywane, jak również klejnoty, złote i srebrne statki" - naczynia ${ }^{326}$.

Z kolei Estera Sádovská z Vchynic ${ }^{327}$ zapisała mężowi cały swój majątek, ze wszystkimi ruchomościami, meblami (nabytky), klejnotami, gotówką, złotem i srebrem, a także šaty své chodicí i také ložni ${ }^{328}$.

Testament równie skąpy w informacje o świecie rzeczy pozostawił Mikuláš Vratislav z Mitrovic (1624) ${ }^{329}$. Dwóm synom, żonie i siedmiu córkom przekazał nieruchomości i rucho-

320 Testament 1867, s. 411-424; por.: Parma T. 2015, s. 203-220.

321 Sondażowa analiza 14 aktów ostatniej woli szeregowego rycerstwa (Ritter) i arystokracji (Herren) z lat sześćdziesiątych XVI w. potwierdza praktykę ograniczania się do ogólnych dyspozycji dotyczących majątku ruchomego (Fahrnis). Legaty pobożne, na rzecz rodziny, przyjaciół (klientów) i służby mają z reguły formę pieniężną, nie rzeczową, por. Seitschek S. 2011, s. 181-195.

${ }^{322}$ Král P. 2002, nr 69, 1618, s. 407: svršky, nábytky, klenoty, hotové penize, listy dlužni.

323 Král P. 2002, nr 70, 1619, s. 410-414.

324 Král P. 2002, s. 413.

325 Král P. 2002, nr 79, 1628, s. 454-459.

${ }^{326}$ Král P. 2002, s. 457: allerley fahrnus, wie die genennet mochten werden, auch an Kleinodien, goldt und silber geschirr.

327 Král P. 2002, nr 80, 1629, s. 459-461.

328 Král P. 2002, s. 460.

${ }^{329}$ Král P. 2002, nr 75, 1624, s. 435-439. 
mości, przede wszystkim sumy w gotówce oraz meble, klejnoty, przywileje — „listy”. O niektórych dowiadujemy się tylko w przypadku żony. Mąż zapisał jej cztery przednie klacze wraz $\mathrm{z}$ nádobím kočárskejm, do tego vůz v nově vobitý pod nebesy, i bydło: dziesięć krów dojnych, pięć jałówek, 150 sztuk owiec, w tym 100 kotnych i 50 jałowych ${ }^{330}$.

Rycerz Jindřich Kouč ${ }^{331}$ cały swój majątek, spisany w odrębnym (nieopublikowanym) inwentarzu, przekazał synowi, Janowi Henrykowi (1610). Chłopiec miał wejść w jego posiadanie dopiero po uzyskaniu pełnoletności. Do tego czasu miała nim zarządzać żona Jindricha — Kateřina. Ona też dysponowała końmi, wozami (wielkim i małym), narzędziami rolniczymi (pługi, brony, radła). Pani Katarzyna uzyskała zgodę na dożywotnie i swobodne korzystanie z wszelkiego majątku testatora, obejmującego wszelkie klejnoty, złote łańcuchy, pierścienie, srebrne puchary, czary, konewki (dzbany), łyżki, szaty ${ }^{332}$. Po śmierci wdowy prawo do tych ruchomości mieli uzyskać stryjowie testatora. W opisie należnych im przedmiotów (oprócz tych stanowiących dożywocie wdowy) znalazły się wcześniej nie wspominane naczynia, nie tylko srebrne, ale też cynowe, a poza strojami dziennymi także szaty do łóżka i piernaty z powleczeniami ${ }^{333}$.

Jeszcze pełniejszy zestaw ruchomości uwzględnił w swym testamencie Václav Bořek Dohalský z Dohalic ${ }^{334}$. Małżonce, która będzie opiekunką czterech nieletnich synów, pozostawił różnorodne dobra, m.in. klejnoty, złoto, srebra, a nadto kosztowne naczynia (srebrne, mosiężne, cynowe, miedziane, żelazne), szaty, piernaty, płótno, ręczniki, obrusy, serwety, przędzę, poza tym skrzynie, łoże, jarmary (almerie? szafy), stoły do pisania (̌̌rejbtise), stoły, zegary i inne sprzęty, inwentarz żywy — bydło (w tym krowy i jałówki), konie (także kobyłki-klacze), oraz zapas wina. Ich posiadanie gwarantowało najwyraźniej, w pojęciu testatora, przyzwoite bytowanie szlacheckiej wdowy z kilkorgiem dzieci.

Wacław nie ograniczył się jednak tylko do podania rodzaju ruchomości, w które powinna być zaopatrzona jego rodzina. Sprecyzował też, które mają stać się jej własnością. Były to: kocz (dotąd używana wraz z szóstką koni) i 6 klaczy (które ma wybrać sobie ze stajni), 2 wozy kryte - nowy i stary, ze skrzyniami i kobiercami, do tego wóz leśny z odpowiednim wyposażeniem. Dla wspomnianej szóstki koni uprząż. Do tego 12 krów, 6 jałowic dwuletnich, 6 wołów trzyletnich, wreszcie kopa owiec ${ }^{335}$. Natomiast złoty łańcuch (za 110 dukatów), według życzenia Václava, miała zachować jego małżonka. Jeśli urodzi córkę, jej powinna przekazać łańcuch, jeśli zaś kolejnego syna - wyrób powinien otrzymać najposłuszniejszy z nich wszystkich ${ }^{336}$.

Podobnie jak w przypadku nielicznych testamentów magnackich, ostatnia wola Bořka zawiera zestawienie rodzajów ruchomości niezbędnych do życia na poziomie szlacheckim, ale także - wyjątkowo - informacje o konkretnych przedmiotach.

Testamenty z takimi bardziej precyzyjnymi dyspozycjami stanowią zdecydowaną mniejszość. Wśród aktów ostatniej woli szlachty jest ich raptem 7 na $29^{337}$, wśród testamentów magnaterii (Panów) - także 7, ale na ogółem $22^{338}$. Stanowią więc odpowiednio 1 i 1/3 opublikowanych dokumentów. W tej sytuacji nie ma sensu poddawać analizie statystycznej zawartych w nich informacji o rzeczach. Warto natomiast podsumować, w których częściach dokumentów

330 Král P. 2002, s. 439.

331 Král P. 2002, nr 61, 1610, s. 367-375.

332 Král P. 2002, s. 373. Podobny, rozszerzony, choć nie traktujący o poszczególnych przedmiotach opis klejnotów i sreber pozostawił Burian Chuchelský, Král P. 2002, nr 81a, 1630, s. 463.

333 Král P. 2002, nr 61, s. 374.

334 Král P. 2002, nr 63, 1612, s. 378-381.

335 Král P. 2002, s. 380. Podobna struktura majątku w testamencie Václava Obytecký, Král P. 2002, nr 99, 1648, s. 534.

336 Král P. 2002, nr 63, s. 381.

337 Král P. 2002, nr 50, 53ab, 62, 63, 65, 75, 87.

338 Král P. 2002, nr 68, 77, 85, 88, 90, 93, $101 \mathrm{ab.}$ 
informacje takie zamieszczano — wśród darowizn na rzecz kościoła, rodziny i przyjaciół, służby i klientów.

Spośród panów (magnatów) wspominany już Jan z Vartemberka ofiarował żonie, obok opisanego ogólnie całego majątku, curiosum — odziedziczony po przodkach róg jednorożca ${ }^{339}$. Jedynym przedmiotem wskazanym w testamencie kolejnego magnata, Vilema młodszego Popela z Lobkovic, jest darowana synom relikwia „ciernia z korony Chrystusa" ${ }^{340}$. Testator wyznaczył opiekuna relikwii; miał nim być najstarszy syn. Zaznaczył też, że żaden z dziedziców nie może się pozbyć tego przedmiotu.

Kilka niecodziennych rzeczy przekazała rodzinie oraz różnym instytucjom kościelnym Judit Magdaléna z Řičan ${ }^{341}$. Był to puchar wykonany z jaja strusiego. Zgodnie z zaleceniem Judit miał być spieniężony, a za uzyskaną kwotę kupiony kielich do katolickiego kościoła w Lounovicach pod Blanikiem, gdzie chciała być pochowana. Na potrzeby tej świątyni kobieta przeznaczyła także zasłony (Firhank). Krewnym, oprócz pieniędzy, oddała mantlik, czepiec perłowy (čepici perlovou), wreszcie złoty krzyżyk z diamentem czeskim ${ }^{342}$.

O paru przedmiotach wspomniał też w swoim testamencie Jan Jiř́ z Žeberka (1639) ${ }^{343}$. Kilka sztuk odzieży dla czterech córek z pierwszego małżeństwa wydzielił z opisanych ogólnie, a przekazanych synom broni (siodła, rynsztunki, pistolety, rusznice, kordy) i szat męskich (chodzonych) $)^{344}$.

Poza gotówką, pewne ruchomości — klejnoty i konie zapisał krewnym i przyjaciołom inny magnat, Heřman Černín z Chudenic $(1650)^{345}$. Wierzchowca brązowego, tureckiego, przeznaczył dla ministra cesarskiego dworu, grafa Bernhardta von Martinitz, zaś białego, tureckiego — dla hrabiego Nostic. Sześć koni powozowych wraz z wozem testator oddał żonie ${ }^{346}$.

Najbogatszy zestaw mienia przeznaczył krewnym, przyjaciołom i klientom (wywodzącym się ze stanów pańskiego, rycerskiego i mieszczańskiego) Jan Litvin z Říčan (1637) ${ }^{347}$. Zapisy obejmowały wartościowe wyroby srebrne oraz cynowe, odzież, kobierce i powozy. Swojej ciotce Jan podarował również pieniądze (3000 kop groszy miśnieńskich). Oprócz rzeczy luksusowych (o których poniżej) ofiarował jej pościel i cynowe świeczniki. Szlachcic Šebastián Pešik, powiernik i być może towarzysz łowów, otrzymał sprzęt i psy myśliwskie ${ }^{348}$. Podobne zapisy można zidentyfikować w testamentach szlachty z Prus Królewskich. Niektórzy z obdarowanych cieszyli się szczególną sympatią testatora (deklarowaną wprost w treści dokumentu), inni zasłużyli na zapis pracą na jego rzecz (np. lekarz).

Testamenty szeregowej szlachty również rzadko zawierają dane o poszczególnych przedmiotach. Ludmila Jenišková z Malevic (1636) wspomina tylko o jednym. Wnuczce, pomijając swoją córkę a jej matkę, zapisała dwa różańce z pereł (páteře) i wszystkie luźne perły ${ }^{349}$.

Nieco bardziej drobiazgowy w kwestii ruchomości był Kryštof Budovec z Budova ${ }^{350}$. Zapisując gros ruchomości małżonce, zastrzegł, które powinna wydać jego stryjowi Wacławowi.

${ }^{339}$ Roh jednorožcový, který jesti po předcích mých zůstal, a žádný neví odkud jesti přišel, Král P. 2002, nr 68, s. 404.

340 Král P. 2002, nr 77, s. 448.

341 Král P. 2002, nr 85, s. 484-485.

342 Král P. 2002, s. 485.

343 Král P. 2002, nr 90, 1639, s. 500-505.

344 Por. Král P. 2002.

345 Král P. 2002, nr 101b, 1650, s. 556-559.

346 Král P. 2002, s. 558.

347 Král P. 2002, nr 88, 1637, s. 493-497.

348 Král P. 2002 s. 495: myslivost [...] chrrty mladé $i$ stare.

349 Král P. 2002, nr 87, 1636, s. 489-492.

${ }^{350}$ Král P. 2002, nr 53b, 1602, s. 329-333. 
Znalazły się wśród nich: szaty do spania i pościel, bielizna stołowa (obrusy, serwety, ręczniki), zastawa cynowa (po trzy puzdra mis i talerzy), wreszcie srebra (o tym niżej). Szaty, najlepsze jakie zostaną, kabat, płaszcz, futra lisie i wilcze wreszcie kalioty (galoty) miał otrzymać szlachcic, Adam Burjan Šlechtov ${ }^{351}$.

Jitka Kamenicka z Holovous ${ }^{352}$, bezdzietna szlachcianka, rozdzielała swój dobytek wśród krewnych, w tym gotówkę, szaty, pościel, bieliznę stołową, cienkie i grubsze płótna, szaty (mentlik), cynowe talerze i konwie, klacze, krowy. Jedna z osób otrzymała 12 łyżek srebrnych $^{353}$.

Charakterystyczny schemat utrwalił się w testamentalnych zapisach szlachty na rzecz wdów. Odchodzący małżonkowie zapewniali im miejsce zamieszkania, a także standardowy zestaw majątkowy: zadaszony powóz (uberdachte Kutsche), do tego ruchomości wniesione w momencie zawarcia związku (wyprawa) lub podarowane przez męża — biżuterię, pościel, zastawę i suknie. Dobrym przykładem tej praktyki jest testament jednego z największych magnatów, kanclerza Królestwa Czeskiego, Adama II z Hradca (1591). Swojej małżonce, Katarzynie hrabiance z Mundfurtu, zapewnił roczny dochód 4000 kop groszy miśnieńskich z zamku Hluboka nad Wełtawą. W razie ponownego zamążpójścia Katarzyna miała otrzymać jednorazowo 12000 zł reńskich. Niezależnie od pieniędzy, Katarzyna zyskała klejnoty, drogie kamienie, przedmioty ze złota i srebra, także puchary i czary (kofliký), które małżonkowie otrzymali jako dary weselne. Jej przypaść miały także osobiste srebra Adama, czyli zastawa na jeden stół (wielkie misy, małe talerze, świeczniki, łyżki i czarki) ${ }^{354}$. Z kolei w aktach ostatniej woli kobiet, z reguły dysponujących niewielkim majątkiem nieruchomym (= gruntowym), częściej można oczekiwać wyliczenia cennych przedmiotów stanowiących osobistą własność testatorki ${ }^{355}$. Sporo szczegółów o skromnych w istocie precjozach zawierał np. testament Doroty Kuklova(ej) spisany na uchodźctwie w Saksonii (1630). Synom Dorota zostawiła srebrny puchar pozłacany z nakrywką (koflik), córkom zaś swoje suknie chodzone (=wierzchnie) (chodici) oraz bransolety złote (orumpant), paski srebrne i pozłacane, srebrne nożenki i pucharki ${ }^{356}$.

Testamenty, także te czeskie, choć jako źródło informacji o otaczających szlachtę rzeczach, wyraźnie ustępują inwentarzom mienia, mają też swoją specyficzną „przewagę" nad rachunkami czy nawet inwentarzami. Wspominane w nich przedmioty miewały dla testatora i spadkobiorców wartość nie tylko materialną i użytkową. Ostatnia wola bywała również świadectwem emocjonalnego stosunku testatora i obdarowywanych do konkretnych rzeczy. Nieraz były one przekazywane z pokolenia na pokolenie, współtworzyły habitus nie tylko testatora, ale też całej szlacheckiej familii, np. biżuteria, srebra stołowe, broń, różne kurioza, w środowisku katolickim dewocjonalia i relikwie ${ }^{357}$. W roku 1603 pewien szlachcic zapisał szwagrowi czarny rapier. Sam używał go najczęściej i miewał w nocy przy łóżku. Wyraził nadzieję, że obdarowany będzie się o ten oręż troszczył tak jako by zlatem neb stř́brem byt ${ }^{358}$. Równie ważne jak wartość kruszcu okazuje się przywiązanie do broni.

\section{Rzeczy luksusowe}

W publikowanym przez Krála zbiorze, testamenty prezentujące luksusowe przedmioty stanowią zdecydowaną mniejszość. Zawierają przy tym wzmianki o jednej, kilku lub najwyżej

351 Král P. 2002, s. 331.

352 Král P. 2002, nr 62, 1611, s. 375-378.

353 Král P. 2002, s. 376.

354 Král P. 1998, s. 507-509.

355 Král P. 2004, s. 486.

356 Bůžek V., Král P. 2007, s. 311.

357 Král P. 2002, s. 65; Král P. 2004, s. 490.

358 Král P. 2002, s. 64, przyp. 266. 
o kilkunastu rzeczach. Dotyczy to zarówno biżuterii, sreber, jak i szat. Spośród tych pierwszych tylko nieliczne są charakteryzowane dokładniej.

Asortyment wspominanych w testamentach k lej n o tó w i s r e b e r nie imponuje. Listę sreber rozdysponowanych przez szlachciankę Annę Pecingarovą (1614) $)^{359}$ otwiera przeznaczony dla syna puchar-czara (koflik) wielki pozłacany, zdobiony srebrnymi pozłacanymi kwiatkami na kształt goździków. Syn przejmie także perły zdobiące kapelusz Anny. Dla brata Jerzego testatorka przeznaczyła gondolę srebrną (gondoli). Siostrze Salomei przypadła ,gallera” srebrna i takiż kubeczek w formie gruszki, drugiej siostrze Katarzynie — dwa srebrne puchary (czary) (kofliky) i czara pozłacana. Obie siostry zyskały do podziału 10 złotych róż, prosty stolik do pisania (biureczko - šrejbtišek), w nim zaś dwie złote zaponki z kamieniem szlachetnym ${ }^{360}$.

Według testamentu wspominanego powyżej rycerza Krzystofa Budovca, jego stryjowi miały przypaść następujące srebra: nalewka z misą (umyvadlo), kubek pozłacany, dwanaście łyżek; bratu stryjecznemu bliżej nieokreślone kubki złote i medale ${ }^{361}$.

Tylko nieco bogatszy jest asortyment precjozów notowanych w testamentach magnackich (pańskich). Hrabia Herman Černin z Chudenic (1650), jeden z najzamożniejszych ${ }^{362}$, dysponujący kilkunastoma posiadłościami o wartości 95000 kop groszy miśnieńskich i 100000 zł reńskich,

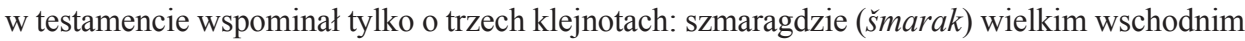
(orientalnym) oprawnym w złoto, w formie dwóch węży, o szafirze (zafir) wielkim, też w złoto oprawnym, wreszcie o łańcuchu złotym otrzymanym od elektora, arcybiskupa Kolonii ${ }^{363}$.

Inny magnat, już przywoływany w tekście, Jan Litvin z Řičan ${ }^{364}$, zapisał ciotce oprócz pieniędzy, 23 srebrne łyżki od dwóch kompletów (każdy według odmiennego wzoru), po cztery tuziny talerzy i mis. Możnemu krewniakowi, stryjowi (Jan Kavka z Ř́čcan, od 1626 r. zarządca, dzierżyciel zamku Karlštejn) pozłacaną konewkę (dzbanuszek — konvičku) oraz cenny — z uwagi na tradycje rodu puchar - czarę (koflik). Wykonał go ręką własną jeden z przodków; został przechowany dla Jana przez ojca, aby jako pamiątka pozostać w posiadaniu rodziny ${ }^{365}$. Hendrych Krumpach, mieszczanin z praskiego Nowego Miasta, służący Janowi w najróżniejszych potrzebach, otrzymał tuzin srebrnych łyżeczek i 5 małych kobierców tureckich, a to na památku a na dokázání vdečností ${ }^{366}$. Innemu mieszczaninowi z Pragi dostał się mały pozłacany kubeczek.

Jeszcze mniej niż o srebrach oraz innych precjozach dowiadujemy się z testamentów o 1 u k s u s o w e j o d z i e ż y. I tak np. szlachcianka Pecingarova (1614) matce, synowi, bratu i dwóm siostrom nie pozostawiła pieniędzy, lecz wiele innych ruchomości, w tym szaty wszelkie „noszone” (chodici - wierzchnie?) suknie, kożuchy, futra do spania, mętliki, ze złotogłowiu, aksamitu i rozlicznych innych materii. Po śmierci matki, siostry miały otrzymać też dwie aksamitne czapeczki wyszywane perłami (czepeczki, mycki?) oraz trzy kapelusiki zdobione perłami i koronkami ${ }^{367}$.

Jan Litvin (1637) ze stanu pańskiego jednemu ze swoich przyjaciół (klientów?) zapisał kożuszek popielaty podszyty sobolami, także płaszcz popielaty ze złotymi guzami, obszyty taśmą. Osobisty lekarz magnata za opiekę nad nim w chorobie otrzymał ubranie adamaszkowe oraz płaszcz aksamitny ${ }^{368}$.

359 Král P. 2002, nr 65, 1614, s. 389-392.

360 Král P. 2002, s. 390.

361 Král P. 2002, nr 53b, s. 330.

362 Král P. 2002, nr 101a, 1650, s. 541-556.

363 Král P. 2002, s. 545.

364 Král P. 2002, nr 88, s. 495.

365 Král P. 2002, s. 495: aby pro památku v rodu našem zůstal.

366 Král P. 2002, s. 495.

367 Král P. 2002, nr 65, 1614, s. 390.

368 Král P. 2002, nr 88, 1637, s. 495. 
Córkom wspominanego powyżej magnata, Jana z Žeberka, przypadły 2 płaszcze — aksamitny czarny i adamaszkowy oraz čepice perlové kupione za 130 kop groszy miśnieńskich. Ta z sióstr, która zatrzyma czepiec, miała spłacić pozostałe.Jeśli to nie będzie możliwe, należy go sprzedać, a uzyskaną z tego tytułu kwotę podzielićc ${ }^{69}$.

\section{Zakończenie}

Przedstawiona powyżej analiza aktów ostatniej woli szlachty z Korony Polskiej i Czech skłania do następujących wniosków co do przydatności tych źródeł w badaniach nad szlacheckim światem rzeczy. W obu krajach przedmiotem testamentalnych dyspozycji majątkowych były definiowane szeroko ruchomości — od gotówki i lokat na dobrach ziemskich, poprzez weksle, kosztowności, odzież, meble, zastawę stołową, sprzęty i naczynia domowe, obicia, książki, obrazy, zegary, dewocjonalia, rynsztunek wojenny, sprzęt myśliwski (w tym psy), powozy, konie oraz pozostały żywy inwentarz, w końcu zarówno zebrane, jak i pozostające na polach płody rolne, a nawet [zdatne do rozbiórki i odtworzenia na innym miejscu - A.K.] „niektóre budowania”. Niekiedy rzeczy ruchome dzielono ze względu na surowiec, z którego je wykonano (np. złoto, srebro, cyna, miedz, mosiądz). Taka struktura majątku ruchomego da się odtworzyć przede wszystkim na podstawie samych testamentów. W niewielkim tylko stopniu jest tu pomocna literatura prawnicza z epoki, w przypadku Polski i Czech późna (XVII-początek XIX w.), zawierająca bardzo niewiele zaleceń dotyczących opisu ruchomości, jeszcze mniej wzorcowych dokumentów. Bardziej pod tym względem przydatne są wydawnictwa niemieckie, głównie z południa i zachodu Rzeszy, wpływające pośrednio na testamentalną praktykę w Czechach i zapewne w Koronie.

Najczęściej testamenty w obu krajach wspominają tylko ogólnikowo o zapisywanych spadkobiercom „rzeczach wszystkich” lub „statku [...] movitym”. Rzadziej pojawiają się informacje o strukturze przekazywanego mienia, ze wskazaniem wspomnianych wyżej kategorii dóbr. Najwięcej testamentów (prawie wszystkie z Czech, ok. połowa z Prus Królewskich, ok. $1 / 3$ z Wielkopolski) zawiera legaty pieniężne. Mniej testatorów podjęło decyzje o dalszych losach konkretnych przedmiotów, głównie o dużej wartości materialnej, prestiżowej, czasami emocjonalnej. Informacje o nich trafiają się zamiast lub obok kwot pieniężnych — wśród legatów dla rożnych osób: członków rodziny, przyjaciół, klientów, służby. Odrębną grupę stanowią zapisy pobożne, dla instytucji kościelnych. W nich oraz w dyspozycjach dotyczących długów, wierzytelności i zastawów zamieszczono najwięcej danych o liczonej w kruszcu albo w monecie wartości danego przedmiotu, jego wielkości, technice zdobienia, o miejscu produkcji. Brak natomiast, nie było to zresztą celem testatorów, rejestru całego, wartego odnotowania majątku ruchomego. Temu służyły inwentarze mienia, tylko wyjątkowo stanowiące integralną część lub załącznik do testamentu.

Przy takich ograniczeniach obraz świata rzeczy tworzony na podstawie testamentów musi być niepełny, w jednych fragmentach przerysowany, czasami wręcz fałszywy.

Analiza testamentów pod kątem obecności wśród dóbr posiadanych przez szlachtę rzeczy zbytkownych, wzmiankowanych w różnych okresach badanego stulecia, od 1/5 do niespełna połowy testamentów z Prus Królewskich i Wielkopolski oraz od 1/4 do 1/3 aktów ostatniej woli z Czech, potwierdziła oczywiste domniemanie o większych ich zasobach u magnaterii i arystokracji (mimo nieuwzględniania w części wielkopańskich testamentów innych dóbr niż pieniądze) niż u szeregowej szlachty. Pozwoliła także na bliższe poznanie asortymentu kosztownej biżuterii, odzieży, zastawy stołowej. Wskazała m.in. na specyficzna rolę guzów — guzików podnoszących wartość poszczególnych sztuk odzieży, a zarazem po odpruciu traktowanych jak biżuteria lub drogie kamienie. Podobną, podwójna rolę dewocjonaliów i biżuterii odgrywały

${ }^{369}$ Král P. 2002, nr 90, s. 503. 
wykonane ze szlachetnych kruszców, zdobione kamieniami albo perłami krzyżyki lub różańce. Potwierdziła też rolę sreber, zwłaszcza łyżek, jako wygodnego zabezpieczenia na przyszłość (legat, zastaw). Wśród zapisywanych elementów srebrnej zastawy stołowej notowano konwie, kubki, puchary, natomiast wyjątkowo rzadko talerze i misy. Trudno jednak tylko na tej podstawie stwierdzić np. że ich nie używano. Z niektórych dokumentów wynika, że zastępowała je cyna przekazywana w całych kompletach, opatrzona znakami herbowymi, a więc ceniona jako majątek rodowy. Atrybutem luksusu były ubiory szyte z różnych rodzajów jedwabiu, z dodatkiem kosztownych futer, np. soboli. W dziedzinie ubioru męskiego w testamentach polskich znajduje wyraźne odbicie rewolucja w modzie. Królujące w pierwszej połowie XVII w. ubiory wierzchnie - delie, ferezje, dołomany, w drugiej zostają wyparte przez kontusze i żupany. W całym badanym okresie tylko pojedyncze testamenty zawierają informacje o ubiorach według mody zachodniej (niemieckiej, francuskiej). W testamentach czeskich jest zbyt mało danych o strojach, by stwierdzić specyfikę w stosunku do mody zachodnioeuropejskiej lub zmian dokonujących się w półwieczu 1600-1650. Za symbol różnic w uzbrojeniu szlachty z obu krajów może uchodzić dla strony polskiej szabla, pochodząca od groźnego przeciwnika Polaków spod Cecory, Dewlet Gereja, przekazywana potem w kolejnych pokoleniach rodów senatorskich i średnioszlacheckich. Dla strony czeskiej to rapier, ulubiona broń testatora, który liczył, że obdarowany nią szwagier będzie się troszczył się o nią tak, jakby była cennym kruszcem.

W obu krajach darzono natomiast przywiązaniem przedmioty codziennego, osobistego użytku, takie jak kufel srebrny średniego szlachcica z Prus, materialny świadek związków z senatorskimi rodami Prus i Kujaw, czy też wykonana własnoręcznie przez jednego z przodków czara, które otrzymał od ojca czeski magnat, Jan Litvin z Řičan.

Wyniki porównania sytuacji w Czechach i w Koronie Polskiej wypada przy tym opatrzyć dużym znakiem zapytania, wynikającym choćby z braku równowagi między bardzo licznym materiałem polskim (setki aktów) oraz wielokrotnie skromniejszym liczebnie czeskim (ok. 50 aktów). Samo porównanie wydaje się jednak usprawiedliwione wobec wyraźnej troski wydawcy testamentów czeskich o reprezentatywność wyboru publikowanych aktów pod względem statusu prawnego testatorów (szlachta wyższa i niższa), struktury płciowej, wyznaniowej (katolicy, protestanci), narodowościowej (język czeski, niemiecki).

Podsumowując, skonstruowanie na podstawie testamentów w miarę pełnego obrazu materialnego otoczenia szlachty polskiej, a tym bardziej czeskiej, nie wydaje się możliwe. Testatorzy z obu krajów w rosnącym stopniu ograniczali dyspozycje majątkowe do zapisów pieniężnych, eliminując $w$ ten sposób z dokumentu opis rzeczy. Testamenty mogą natomiast stanowić cenne uzupełnienie źródła w tej mierze podstawowego — inwentarza mienia. Nieliczne akty ostatniej woli zawierają tym cenniejsze, szczegółowe informacje o najbardziej wartościowych pod względem materialnym, prestiżowym czy emocjonalnym przedmiotach; o ich pochodzeniu, wytwórcach, cenie, funkcjach, kształcie estetycznym. Dane o podobnym charakterze może też przynieść kwerenda w słabiej dotychczas pod tym kątem analizowanych, pokrewnych źródłach — aktach działów majątkowych, intercyzach ślubnych, rejestrach posagów i wypraw.

Adres Autora:

Prof. dr hab. Andrzej Klonder

Instytut Archeologii i Etnologii PAN

al. Solidarności 105

00-140 Warszawa

andrzej.klonder@gmail.com

http://orcid.org/0000-0002-7542-0929 


\section{BIBLIOGRAFIA}

\section{Źródła i opracowania opublikowane}

Aristokratické 1999. Aristokratické rezidence a dvory v ranem novověku, Opera historica, t. 7, red. V. Bůžek, P. Král, České Budějovice.

Auer Leopold. 2011. Reichshofrätliche Testamente, Sperr - und Verlassenschaftsabhandlungen im Haus- Hof- und Staatsarchiv, „Beiträge zur Rechtsgeschichte Österreichs”, 1, 2011.

Bůžek Vaclav. 1995. Rytíri renesančních Čech, Praha.

Bůžek Vaclav. 2001. Tendencje rozwu życia codziennego w poludniowo-czeskich mieszczańskich gospodarstwach domowych we wczesnej nowożytności, „Kwartalnik Historii Kultury Materialnej”, R. XLIX, nr 1-2, s. 13-40.

Bůžek Vaclav, Král Pavel. 2007. Človek českeho raneho novoveku, Praha.

Ciara Stefan. 1980. Kariera rodu Wejherów 1560-1657, Warszawa.

Cui contingit nasci. 2005. Cui contingit nasci, restat mori. Wybór testamentów staropolskich z województwa sandomierskiego 2005, oprac. M. Lubczyński, J. Pielas, H. Suchojad, Warszawa.

Czerwiński Ignacy. 1810. Przewodnik testatora, czyli ważne uwagi z dwóch części złożone. Jak? i o czym? testamenta pisać się powinny, Lwów.

Dąbkowski Przemysław. 1911. Prawo prywatne polskie, t. II, Lwów.

Dygdała Jerzy. 2014. Testamenty szlachty Prus Królewskich z XVII wieku, rec. w: „Zapiski Historyczne", t. LXXIX, z. 1, s. 137-140.

Fauknar Šebastian z Fonkenštejna. 1589. Tytulař. Formy listů rozličných, Staré Město Pražske.

Gołembiowski Maciej. 1988. Kilka uwag o testamentach z XVII i XVIII wieku w księgach biskupstwa Chetmińskiego, [w:] W kręgu stanowych i kulturowych przeobrażeń Europy Pótnocnej w XIV$-X V I I I$ wieku, red. Z.H. Nowak, Toruń, s. 159-177.

Górny Marek. 2002. Testament Macieja Grochowickiego łowczego kaliskiego z 1675 roku, „Genealogia”, t. 14.

Grzegorz Gdański. 1996. O. Grzegorza Gdańskiego Kronika Klasztoru Franciszkanów Ściślejszej obserwancji w Wejherowie w latach 1633-1676, wyd. G. Labuda, Wejherowo.

Hrubá Michaela. 2001. Renesansowe rezydencje szlachty w pótnocno-zachodnich Czechach w świetle inwentarzy majątkowych, „Kwartalnik Historii Kultury Materialnej”, R. XLIX, nr 1-2, s. $59-80$.

Hrubá Michaela. 2002. „Nedávej statku žádnému dokud duše v téle”. Pozůstalostní praxe a agenda královských měst severozáapdnich Čech v predbělohorské době, Ústí nad Labem.

Hrubá Michaela. 2015. Testament jako źródło do studium pamięci o zmartych w miastach pótnocnozachodnich Czech $w$ dobie nowożytnej, [w:] Nie wszystek umrę. Pamięć o zmarlych w kulturze staropolskiej, red. A. Jankowski, A. Klonder, Bydgoszcz, s. 58-69.

Kalinowska B[arbara]. 2000. Testament Tomasza Gocłowskiego sędziego ziemi nurskiej, „Mazowsze”, 13, s. $125-128$.

Král Pavel. 1998. Pohřby poślednich pánů z Hradce, Opera Historica, t. 6, red. V. Bůžek, České Budéjovice, s. 401-512.

Král Pavel. 2002. Mezi životem a smrtí. Testamenty české šlechty v letech 1550 až 1650, České Budějovice.

Král Pavel. 2004. Heiratsverträge und Testamente in Böhmen im 16. und 17. Jahrhundert, [w:] Quellenkunde der Habsburgermonarchie (16.-18. Jahrhundert), red. I. Pauser, München.

Kutrzeba Stanisław. 1921. Historia źródeł dawnego prawa polskiego, t. 1, Lwów.

Landes-Ordnung. 1678. Verneuerte Böhmische und Mährische Landes-Ordnung, Prag.

Malý Tomaš. 2011. Böhmische und mährische Bürgertestamente der frühen Neuzeit. Voraussetzungen, Praxis, Rezeption, „Beiträge zur Rechtsgeschichte Österreichs”, 1.

Nowak Tomasz A. 2013. Testament Wojciecha z Woli Wężykowej Wężyka z 1689 r., „Zeszyty Wiejskie”, z. 18 , s. 293-302.

Ostrowski Teodor. 1787. Prawo cywilne polskie, t. II, Warszawa.

Parma Tomáš. 2015. Commendantes corpus nostrum examine terrae. Biskupské testamenty kardinála Dietrichsteina a jeho pohřb v olomoucké katedrále, „Studia theologica”, t. 17, $\mathrm{nr} 2$.

Peneder Andreas, Hunger Wolfgang. 1721. Institutiones Testamentariae, oder Vollständige Nachricht von Testamenten und Codicillen, Frankfuhrt-Leipzig. 
Pešek J[aromir]. 1982. Pražské knihy kšaftů a inventář̀. Př́spěvek k jejich struktuře a vývoji v době předbělhorské, „Pražský sbornik historický”, 15, s. 63-93.

Pielas Jacek. 2004. Majątek ziemski i ruchomy zamożnej szlachcianki w końcu XVI wieku. Przyczynek do dziejów linii Tarłów herbu Topór, „Między Wisłą a Pilicą. Studia i materiały historyczne”, t. 5, s. 307-315.

Pielas Jacek. 2009. Wdowa - matka a kwestie majątkowe w rodzinach szlachty koronnej w XVII wieku, [w:] Społeczeństwo staropolskie, Seria Nowa, t. III, red. A. Karpiński, Warszawa, s. $171-193$.

Pielas Jacek. 2013. Podziały majatkowe szlachty koronnej w XVII wieku, Kielce.

Pielas Jacek. 2015. Decyzje szlacheckich spadkodawców i ich respektowanie przez sukcesorów dóbr ziemskich $w$ Koronie z XVII wieku, [w:] Nie wszystek umrę. Pamięć o zmarlych $w$ kulturze staropolskiej, red. A. Jankowski, A. Klonder, Bydgoszcz.

Pielas Jacek. 2016. Dziedziczenie dóbr nieruchomych przez szlachcianki w Rzeczypospolitej XVI-XVIII w. na tle porównawczym, [w:] Od mistyczki do komediantki. Kobiety Europy epok dawnych - źródła i perspektywy, red. J. Godlewicz-Adamiec i in., Warszawa, s. X-X.

Popiołek Bożena. 2009. Woli mojej ostatniej testament ten... Testamenty staropolskie jako źródło do historii mentalności XVII i XVIII wieku, Kraków.

Rauscher Rudolf. 1922. Dédické právo podle českého práva zemskeho, Bratislava.

Sattler Johann Rudolph. 1619. Thesaurus notariorum, Basel.

Saur Abraham. 1607. Dives notariorum penus, Franckfort am Mayn.

Seitschek Stefan. 2011. ,, in der allen bessten formb”. Adlige Testamente der 1560er Jahre, „Beiträge zur Rechtsgeschichte Österreichs", 1, s. 181-195.

Sulej Katarzyna. 2009. Mariaże magnackie w XVI-XVIII wieku na podstawie intercyz przedślubnych, [w:] Społeczeństwo Staropolskie, Seria Nowa, t. III, red. A. Karpiński, Warszawa, s. 63-97.

Sygański Jan. 1910. Z życia domowego szlachty sądeckiej w epoce Wazów, Lwów.

Śliż N[atalia]. 2007. Testament Piotra Kochlewskiego, sędziego ziemskiego brzeskiego z 1645 roku, „Zapiski Historyczne”, 77, z. 1, s. 91-103.

Testament. 1867. Testament des Cardinals olmützer Fürstbischofs und Mährischen Landeshauptmanns Franz Fürsten von Dietrichstein, wyd. Ch. d'Elvert, Brunn.

Testamenty. 1997. Testamenty szlachty krakowskiej XVII-XVIII w., oprac. A. Falniowska-Gradowska, Kraków.

Testamenty. 2007. Testamenty Jana, Tomasza i Jana ,Sobiepana” Zamoyskich, oprac. W. Kaczorowski, Opole.

Testamenty. 2008. Testamenty szlacheckie z ksiag grodzkich wielkopolskich z lat 1631-1655, wyd. P. Klint, Poznań-Wrocław.

Testamenty. 2011. Testamenty szlacheckie z ksiag grodzkich wielkopolskich z lat 1657-1680, wyd. P. Klint, Wrocław.

Testamenty. 2013. Testamenty szlachty Prus Królewskich z XVII, wyd. J. Kowalkowski, W. Nowosad, Warszawa.

Testamenty. 2014. Testamenty z XVII i XVIII w. szlachty i duchowieństwa z Podlasia, wyd. J. Mamaj, Warszawa.

Testamenty. 2015. Testamenty szlacheckie z ksiag grodzkich wielkopolskich z lat 1681-1700, wyd. P. Klint, Wrocław.

Testamenty. 2018. Testamenty szlacheckie z ksiag grodzkich i ziemskich ziemi halickiej z XVII wieku, wyd. P. Klint, K. Rzemieniecki, J. Węglorz, Wrocław.

Testamenty Zygmunta III Wazy. 2013. Testamenty Zygmunta III Wazy, wyd. W. Kaczorowski i in., Opole.

Turnau Irena. 1999. Stownik ubiorów, Warszawa

Vaněček Václav. 1964. Dějiny státu a práva v československe do roku 1945, Praha.

Volckmann Adam. 1655. Neu-verbesserte Notariat- Kunst, Leipzig.

Wilczek-Karczewska Magdalena. 2011. Testamenty szlachty wielkopolskiej z XVII w., „Kwartalnik Historii Kultury Materialnej”, R. LIX, nr 3-4, s. 333-345.

Wróbel Elżbieta Elena. 2015. Istotne pytania zwiąane z edycja testamentów duchownych okresu staropolskiego, „Kwartalnik Historii Kultury Materialnej”, R. LXIII, nr 4, s. 577-584. 
Wróbel Elżbieta Elena. 2016. Kościołowi mojemu jako ukochanej oblubienicy moje. Wybór testamentów duchownych matopolskich z XVII wieku, Kraków

Zalaszowski Mikołaj. 1702. Juris Regni Polonae, t. II, Posnaniae.

Zielecka Mikołajczyk Wioletta. 2012. Prawosławni i unici w Rzeczypospolitej XVI-XVIII wieku wobec życia i śmierci $w$ świetle testamentów, Warszawa.

Život. 1996. Život na dvorech barokní šlechty (1600-1750), Opera Historica 5, red. V. Bůžek, České Budějovice.

Żołądź-Strzelczyk Danuta. 2009. Sprawy rodzinne, oświatowe i obyczajowe w Aktach Synodu Braci Czeskich w Wielkopolsce w XVI-XVII wieku, [w:] Społeczeństwo Staropolskie. Seria Nowa, t. III, red. A. Karpiński, Warszawa, s. 99-129.

\section{The world of material objects in testaments of Polish and Czech nobility in the 17 th century}

The author's inspiration to research the topic specified in the title was two-fold. The first motive were historians' divergent opinions on the usefulness of last wills in researching the material culture of nobility. Researchers from Poland, the Czech Republic and German-speaking countries are divided, some being enthusiastic and some highly sceptical about using last wills as sources, with the sceptics stressing that unlike in inventories, in last wills movables are of secondary importance. Such opinions have usually been formulated incidentally in connection with some other topics.

Secondly, recent decades have seen the editing of nobility testament from Polish archives on an unprecedented scale (e.g. c. 600 testaments of nobility from Greater Poland and c. 100 from Royal Prussia have been published). Furthermore, the end of the 20th c. was marked with an increased interest in nobility among Czech historians. This has created an opportunity of comparing the usefulness of testaments in exploring the material world of nobility in the two countries, taking into account that in terms of the social and economic structure the two mentioned provinces (Greater Poland and Royal Prussia) were not as different from Bohemia as the eastern parts of the Polish-Lithuanian Commonwealth.

The analysis of data on movables (the world of material objects) contained in testaments is preceded with a survey of legal texts from the 17th-early 19th c., which in the case of Poland and Bohemia included very few guidelines concerning descriptions of movables and even fewer model documents. More helpful in this respect are publications from southern and western Germany, which were used in the practice of last-will making in Bohemia, and possibly in the Crown of Poland.

The analysis of nobility testaments from the Crown of Poland and Bohemia led to the following conclusions. In both countries many last wills mentioned widely understood movables, ranging from cash and investments in estates through bills of exchange, valuables, clothes, furniture, tableware, dishes, tapestries, books, paintings, clocks, devotional items, battle gear, hunting equipment and dogs, carriages, horses and other livestock, to harvested and unharvested crops and even buildings that could be dismantled and re-erected elsewhere. Sometimes movables were classified according to the material (e.g. gold, silver, tin, copper, brass).

The documents that were analysed usually mentioned the movables bequeathed very enigmatically (e.g. as 'all the things') and rarely included information on the structure of the bequeathed movable property in terms of the aforementioned categories of objects. Most of the testaments (almost all from Bohemia, about a half from Royal Prussia and about 1/3 from Greater Poland) listed money bequests. Fewer testators bequeathed particular objects, usually 
of significant material or emotional value. Data on them can be found among bequests to relatives, friends, clients or servants. A separate category are bequests to Church institutions. It is in them, and in dispositions concerning debts, liabilities and pledges, that most data can be found on the value, size, decoration or provenance of particular objects. Testaments normally lacked descriptions of the whole movable property - this was the function of probate inventories, which rarely were integral parts of or appendices to last wills. Due to such limitations the picture of the world of objects arising from testaments is necessarily fragmentary.

A separate analysis concerning luxury items was made (on the basis of documents from different periods within the century in question, from $1 / 5$ to $1 / 2$ of the testaments from Greater Poland and Royal Prussia, and from $1 / 4$ to $1 / 3$ of the testaments from Bohemia). It confirmed that, as predicted, much more of such items were owned by aristocrats and magnates than by low-status nobles. It also showed the range of bequeathed jewellery, clothing and tableware. It revealed the special role of large ornamental buttons, which increased the value of garments or, when cut off, were treated on a par with jewellery and gems. A similar double role, of devotional items and jewellery, was characteristic of crosses and rosaries made of noble metals and decorated with precious stones or pearls. The analysis also confirmed the importance of silverware, especially spoons, which served as security (e.g. as legacy or pledge). The most frequently listed pieces of silverware were cans, mugs and goblets. Silver plates and bowls were less commonly encountered but this is not a sufficient basis to conclude that they were not used. Some testaments indicate that they were replaced by tin dishes, bequeathed in whole sets decorated with coats of arms, which means they were treated as family heirlooms. In both countries an important attribute of luxury were garments sewn of different kinds of silk lined with expensive furs, e.g. sable. The Polish testaments clearly reflect changes in men's fashion: delia, ferezja and dolman, overcoats typical of the first half of the 17th c., in the second half are replaced by kontusz and zupan. Only a few testaments within the whole corpus mention garments made according to the Western fashion (French or German). The Czech testaments do not contain enough information on clothes to draw any conclusions about their relationship to Western fashion or about the changes in the 1600-1650 period.

In both countries testators were emotionally attached to weapons and some everyday objects. In Bohemia such an item could be one's father's rapier, in Poland - a sabre. A silver beer-mug owned by a nobleman from Royal Prussia testified to his relationship with senator families. The Czech magnate Jan Litvin of Řčany was particularly concerned about a goblet made by one of his ancestors.

Reconstructing a full picture of the material surroundings of Polish, let alone Czech, nobility on the basis of last wills does not seem feasible. Testators from both countries gradually limited their bequests to money, thus eliminating descriptions of objects from testaments. Nevertheless, last wills can be treated as a valuable supplement of the basic source type, i.e. probate inventories. Very few last wills contain data on objects of high material, emotional or prestige-related value: on their provenance, makers, price, functions, aesthetics (gifts, pledges). Such data can potentially be obtained by researching similar types of sources, poorly explored so far: records of estate distribution, prenuptial agreements, or dowry registers.

Translated by Izabela Szymańska 